\title{
V. CENOZOIC SILICOFLAGELLATE AND COCCOLITH STRATIGRAPHY, SOUTH ATLANTIC OCEAN, DEEP SEA DRILLING PROJECT LEG 36
}

\author{
David Bukry, United States Geological Survey, La Jolla, California
}

\section{INTRODUCTION}

Leg 36 of the Deep Sea Drilling Project, March to May 1974, which began at Ushuaia, Argentina, and ended at Rio de Janeiro, Brazil (Figure 1), recovered 102 cores at six drilling sites, Sites 326-331. Light-microscope techniques were used to study the silicoflagellates and coccoliths of 115 samples of Cenozoic age. Most of my study time for Leg 36 sites was devoted to the very diverse silicoflagellate assemblages of the upper Paleocene at Site 327 and the upper Oligocene at Site 328.

New species and subspecies of silicoflagellates from DSDP Leg 36 are Corbisema disymmetrica angulata, $C$. disymmetrica communis, $C$. falklandensis, $C$. glezerae, $C$. hastata cunicula, C. hastata globulata, $C$. inermis crenulata, C. neoparallela, Dictyocha fibula augusta, D. fischeri, D. precarentis, Distephanus crux darwinii, and D. raupii. New taxonomic combinations are Corbisema disymmetrica disymmetrica, $C$. inermis minor, Distephanus speculum triommata, and Naviculopsis ponticula.

\section{SILICOFLAGELLATE COUNTING AND PROCESSING}

Counts of silicoflagellate assemblages were done by mechanical-stage traverses of one to four slides for each sample using smear slides prepared from unprocessed sediment and strewn slides of acid residues. To help prevent size fractionation of the original fossil assemblage, no sieving or settling techniques were employed. Identifications were made primarily at magnification $500 \times$.

\section{ZONATION}

Zonation of Cenozoic strata from DSDP Leg 36 is facilitated by especially diverse silicoflagellate assemblages that can be assigned to zones previously described from the Pacific and Southern oceans (Bukry and Foster, 1973; Bukry, 1975d). Coccolith diversity is generally so low that only broad age estimates, based on a few cosmopolitan species, are possible. Only in the Paleogene are coccoliths sufficiently diverse to permit recognition of low-latitude zones (see Site Summaries).

Although the abundance and ranges of several silicoflagellates tabulated for Leg 36 might provide a basis for new biostratigraphic units, none are proposed because of present taxonomic instability and because stratigraphic ranges are only partially determined. The silicoflagellate zones used for Leg 36 cores (Figure 2) are discussed below, from oldest to youngest.

\section{Corbisema hastata Zone (Bukry and Foster, 1974)}

The base of the Corbisema hastata Zone, marked by the first appearance of Corbisema hastata, was deter- mined to be near the base of the lower Paleocene by deep-sea drilling in the Pacific (DSDP Site 208); the upper part of the zone was not recovered there. At Hole $327 \mathrm{~A}$ in the South Atlantic, the first common occurrence of Naviculopsis constricta, which defines the upper limit of the zone, is recorded in Core 5A. Associated coccoliths are of late Paleocene age. Therefore, the $C$. hastata Zone seems to be restricted to the Paleocene.

\section{Naviculopsis constricta Zone (Bukry and Foster, 1974)}

The lower limit of the Naviculopsis constricta Zone, based on the lowest common occurrence of Naviculopsis constricta, occurs in Core 5A in Hole 327A. Marked increases in abundance of Corbisema disymmetrica angulata and $C$. hastata cunicula relative to older Cores $6 \mathrm{~A}$ to $8 \mathrm{~A}$ are noted in Core $5 \mathrm{~A}$. Association of the coccolith guide species Heliolithus riedelii with $N$. constricta in Core $5 \mathrm{~A}$ helps date the base of the zone as late Paleocene.

\section{Dictyocha deflandrei Zone, Naviculopsis trispinosa Subzone (Bukry, 1975d)}

The single silicoflagellate sample from Core 5 in Hole 328B is dominated by Naviculopsis constricta and contains $N$. biapiculata, $N$. trispinosa, Dictyocha aspera martinii, $D$. deflandrei, and $D$. hexacantha (reworked?). The numerical dominance of $N$. constricta over $N$. biapiculata and $D$. aspera martinii and $D$. deflandrei over $D$. hexacantha are characteristic of the $N$. trispinosa Subzone in Hole 328B and Site 283 in the Southern Ocean. Although the sediment at $328 \mathrm{~B}$ is noncalcareous, a late Eocene age is assigned because coccoliths of the late Eocene Chiasmolithus oamaruensis Subzone are associated with the N. trispinosa Subzone at Site 283.

\section{Naviculopsis biapiculata Zone (Bukry, 1974)}

A rather complete section of the Naviculopsis biapiculata Zone, as suggested by the distributions of Dictyocha deflandrei, Mesocena pappii, Naviculopsis biapiculata, and $N$. trispinosa, occurs in Cores 3B to 4B in Hole 328B. Although no coccoliths occur in this section, the late Oligocene diatom Stictodiscus gelidus (?syn. Rocella gemma; compare Plate 9, Figures 4-9 to Hanna, 1929, 1930), formerly considered a silicoflagellate, has its characteristic acme in Core 3B (Table 1).

A marked change in silicoflagellate assemblage composition in the lower part of Core 3B makes the upper $N$. biapiculata Zone distinctive in Hole 328B: Distephanus crux darwinii first appears in abundance; Distephanus speculum varieties with divided apical rings first appear; and Distephanus crux crux and Naviculopsis trispinosa decrease sharply. D. crux darwinii is associated with the late Oligocene coccoliths Cyclicargo- 


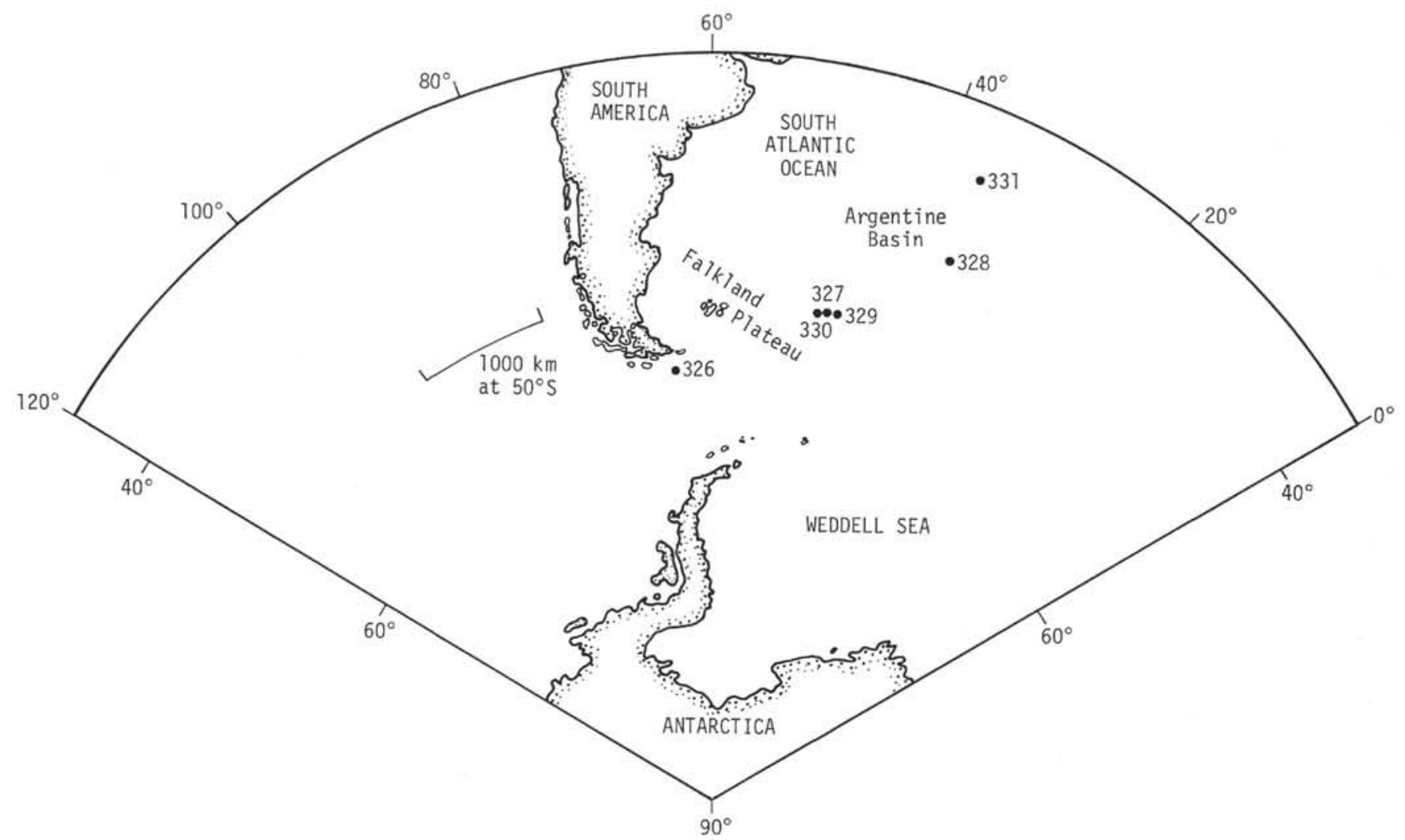

Figure 1. Location of coring sites, Deep Sea Drilling Project Leg 36.

\begin{tabular}{|c|c|c|c|c|c|}
\hline \multirow{2}{*}{ Age } & \multirow{2}{*}{ Zone } & \multicolumn{4}{|c|}{ DSDP Site } \\
\hline & & 327 & 328 & 329 & 331 \\
\hline Quaternary & $\begin{array}{l}\text { Diotyocha } \\
\text { asileata }\end{array}$ & & $1 A-1 \& 1-3$ & & $1-4$ \\
\hline P1focene & $\begin{array}{l}\text { Diatephanus } \\
\text { bolivienais } \\
\text { bolivieneis }\end{array}$ & \multirow{4}{*}{$? 1-3$} & $1 B-2 / 1 B-4$ & & \\
\hline \multirow{3}{*}{ Miocene } & $\begin{array}{l}\text { Distephanus } \\
\text { apecilizin } \\
\text { epeoulion }\end{array}$ & & ?3-1/3-2 & $1-3 / 14-2$ & \\
\hline & {$\left[\begin{array}{l}\text { Mesocena ciroutus } \\
\text { Subzone }\end{array}\right]$} & & & & \\
\hline & - & & & $15-2 / 27-1$ & \\
\hline 01 igocene & $\begin{array}{l}\text { Naviculopais } \\
\text { biapicilata }\end{array}$ & & $3 B-1 / 48-5$ & & \\
\hline Eocene & $\begin{array}{l}\text { Diotyocha deflondrei } \\
{\left[\begin{array}{l}\text { Naviouiopsis } \\
\text { triapinosa } \\
\text { Subzone }\end{array}\right]}\end{array}$ & & $58-2$ & & \\
\hline \multirow{3}{*}{ Paleocene } & $\begin{array}{l}\text { Naviculopsis } \\
\text { constriota }\end{array}$ & $5 A-1 / 5 A-4$ & & & \\
\hline & $\begin{array}{l}\text { N. conetriota } \\
\text { or } \\
\text { c. hastata }\end{array}$ & $5 A-5 / 7 A-2$ & & & \\
\hline & $\begin{array}{l}\text { Corbisenia } \\
\text { hastata }\end{array}$ & $8 A-1 / 8 A-3$ & & & \\
\hline
\end{tabular}

Figure 2. Silicoflagellate zonation of core samples from DSDP Leg 36. The numbers assigned to zonal intervals are core and section numbers of samples examined. Where a zone is represented in more than two samples, the highest and lowest are listed separated by a slash.

lithus abisectus and Dictyococcites bisectus in the North Atlantic at Site 338. The acme of Distephanus raupii (syn. Distephanus speculum pentagonus with small apical openings) recorded above the range of $N$. biapiculata at Site 278 (Bukry, 1975d), appears within the range of $N$. biapiculata in Hole 328B; this points up the need for more control points to help establish the most consistent criteria for silicoflagellate biostratigraphy and paleoecology.

Distephanus speculum speculum Zone, Mesocena circulus Subzone (Bukry, 1975d)

The silicoflagellate assemblages of a thick upper Miocene section at Site 329 (Cores 1 to 14) are largely dominated by Mesocena circulus and the Distephanus speculum group. The top of the subzone was not sampled at Site 329, but the base of the subzone is indicated by the first abundant occurrence of $M$. circulus in Core 14. Mesocena diodon occurs through most of the range of $M$. circulus at Site 329. Several late Miocene samples from Site 328 are tentatively assigned to this subzone, but $M$. circulus is not especially abundant. Dictyocha aspera clinata, a late Miocene species in the North Pacific, occurs at Site 328 , providing an auxiliary indicator for this assignment.

\section{Distephanus boliviensis boliviensis Zone \\ (Bukry and Foster, 1973)}

An abundant occurrence of the large species Distephanus boliviensis boliviensis above the last common Dictyocha aspera clinata and Mesocena circulus in Core 1B in Hole 328B is used to help identify this zone. First described from low latitude at Site 157 at the northern limit of the cool Peru Current, the Distephanus boliviensis boliviensis Zone is probably more applicable to high-latitude assemblages because its key species, $D$. 
TABLE 1

Acme of Late Oligocene Diatom

Stictodiscus gelidus Mann (?Synonym:

Rocella gemma Hanna) Illustrated by

Number Intersected During Counts of 300 Silicoflagellates per Sample in Hole 328B

\begin{tabular}{lcc}
\hline $\begin{array}{c}\text { Sample } \\
\text { (Interval in cm) }\end{array}$ & $\begin{array}{c}\text { Depth } \\
(\mathrm{m})\end{array}$ & $\begin{array}{c}\text { Total } \\
\text { Stictodiscus } \\
\text { gelidus }\end{array}$ \\
\hline $3-1,109-110$ & 28 & 19 \\
$3-3,95-96$ & 31 & 15 \\
$3-5,100-102$ & 34 & 195 \\
$3-6,50-52$ & 35 & 618 \\
$4-1,60-62$ & 37 & 43 \\
$4-3,60-62$ & 40 & 17 \\
$4-5,60-62$ & 43 & 0 \\
$5-2,60-62$ & 48 & 0 \\
\hline
\end{tabular}

boliviensis boliviensis, is more abundant there and is missing in strictly tropical assemblages of Pliocene age such as at Site 77 (Bukry, 1976). D. boliviensis boliviensis has been recorded in Pliocene strata at several sites in the Southern Ocean (Ciesielski and Weaver, 1973).

\section{Dictyocha aculeata Zone (Bukry and Foster, 1973)}

The first occurrence and range of cosmopolitan Dictyocha aculeata ( $D$. epiodon of other reports) defines an upper Quaternary zone in subpolar as well as in equatorial areas. The geographic range of D. aculeata in the North Pacific Ocean from latitude $0^{\circ}$ to $60^{\circ} \mathrm{N}$ (Poelchau, 1974) complements its occurrence at DSDP Sites 328 and 331 in the South Atlantic Ocean at latitudes $50^{\circ} \mathrm{S}$ and $38^{\circ} \mathrm{S}$. The zonal assemblages from Leg 36 have low diversity with Dictyocha stapedia stapedia or D. speculum speculum dominant.

\section{SITE SUMMARIES}

\section{Site 326}

\section{(lat $56^{\circ} 35.00^{\prime} \mathrm{S}$, long $65^{\circ} 18.20^{\prime} \mathrm{W}$, depth $3812 \mathrm{~m}$ )}

No samples available; see reports of shipboard scientists.

Site 327

(lat $50^{\circ} 52.28^{\prime} \mathrm{S}$, long $46^{\circ} 47.02^{\prime} \mathrm{W}$, depth $2401 \mathrm{~m}$ )

Site 327, on the eastern end of the Falkland Plateau, was drilled to determine the age and composition of acoustic-reflector horizons in Cretaceous and lower Tertiary strata.

Phytoplankton assemblages of the 80-meter Cenozoic section are dominated by silicoflagellates and diatoms. Coccoliths are abundant in only a few samples, diversity is low, and moderate to intense solution is evident. Sample $327 \mathrm{~A}-2-1,126-127 \mathrm{~cm}(14 \mathrm{~m})$ contains a cool-water assemblage dominated by rims of Chiasmolithus spp. The occurrence of rare Discoaster barbadiensis, Thoracosphaera prolata, and common Reticulofenestra $\mathrm{sp}$. cf. $R$. samodurovii suggests middle Eocene. The only other abundant age-diagnostic assemblages are from Core 5A (42 to $52 \mathrm{~m})$. The cool-water upper Paleocene assemblages are dominated by Chiasmolithus bidens, Fascicu- lithus involutus, and Toweius eminens. Other species present include: Coccolithus pelagicus s. ampl., Cyclococcolithina? robusta, Discoaster mediosus, Ellipsolithus distichus, Heliolithus riedelii, Neochiastozygus chiastus, and $N$. distentus. The deepest coccolith-bearing Cenozoic sample, 327A-7-2, 3-4 cm (62 m), contains only a few specimens of the three dominant species of Core 5.

Silicoflagellates are most abundant in the upper Paleocene samples from Cores 5A to 8A (Table 2). Among shallower samples, only the mixed late Miocene and Pliocene assemblage of $327-1-3,69-70 \mathrm{~cm}(4 \mathrm{~m})$ is abundant enough for an accurate count of ratios. The taxa Dictyocha aspera clinata and Distephanus boliviensis frugalis, recently described from the late Miocene of the North Pacific (Bukry, 1975c), occur with Distephanus boliviensis boliviensis, Corbisema triacantha, and a large array of variants of other species, suggesting mixing as a result of reworking.

The Paleocene silicoflagellate assemblages are characterized by the dominance of Corbisema hastata and its subspecies. Preservation is excellent, and the transition from the Corbisema hastata Zone to the Naviculopsis constricta Zone is recorded for the first time at this site (see Zonation).

\section{Site 328}

(lat $49^{\circ} 48.67^{\prime} \mathrm{S}$, long $36^{\circ} 39.53^{\prime} \mathrm{W}$, depth $5013 \mathrm{~m}$ )

Site 328 is east of the Falkland Plateau in the area where Antarctic bottom water flows from the Weddell Sea into the Argentine Basin. Coring was intended to provide a deep-water reference section for comparison to the Falkland Plateau and to record the initiation of the Antarctic circumpolar current.

Although coccoliths are absent in the Cenozoic section (Cores 1 to $5 \mathrm{~B}, 0$ to $51 \mathrm{~m}$ ), silicoflagellates are abundant at many levels, providing evidence for the presence of Quaternary, Pliocene, upper Miocene, upper Oligocene, and upper Eocene strata (Tables 3 and 4). The cool-water genus Distephanus predominates, but cosmopolitan or cool-water members of Dictyocha such as $D$. aculeata, D. aspera clinata, and D. stapedia stapedia also aid in biostratigraphic determinations (see Zonation). Reworking of older taxa is more sporadic and less common than at Site 329 on the Falkland Plateau.

\section{Site 329 \\ (lat $50^{\circ} 39.31^{\prime} \mathrm{S}$, long $4^{\circ} 05.73 ' \mathrm{~W}$, depth $1519 \mathrm{~m}$ )}

Site 329, on the eastern end of the Falkland Plateau, upslope from Site 327, was cored to determine the age and composition of the Neogene strata on the plateau for comparison with Site 328 and to investigate paleocirculation in the South Atlantic Ocean.

Coccoliths are present throughout the cored interval, upper Paleocene to upper Miocene, but coccolith diversity is so low in the diatom- and silicoflagellate-rich Neogene (Cores 1 to 27,0 to $370 \mathrm{~m}$ ) that no existing coccolith zonation can be recognized. The biostratigraphic utility of the basically tropical group of calcareous nannofossils is reduced in the Neogene in cold-water areas (Bukry, 1975a) because of low diversity and long ranges. The reduction in resolution is compounded at Site 329 by pervasive reworking. A typical Neogene assemblage, such as that of Sample 329-4-5, 50-51 cm (34 m), con- 
TABLE 2

Silicoflagellates in Upper Paleocene Samples from Hole 327A Recorded as Percents

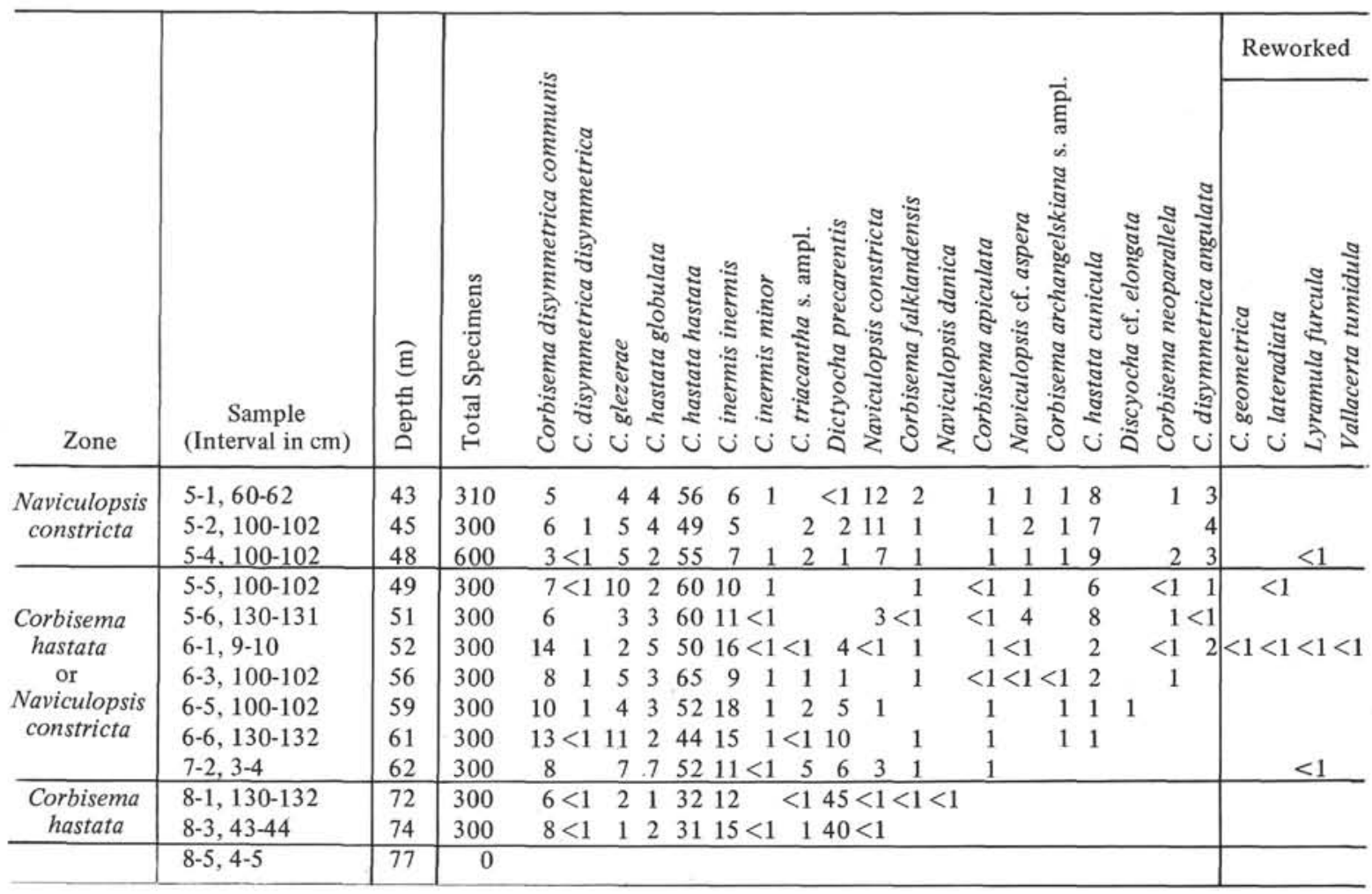

TABLE 3

Silicoflagellates in Samples from Hole 328B Recorded as Percents

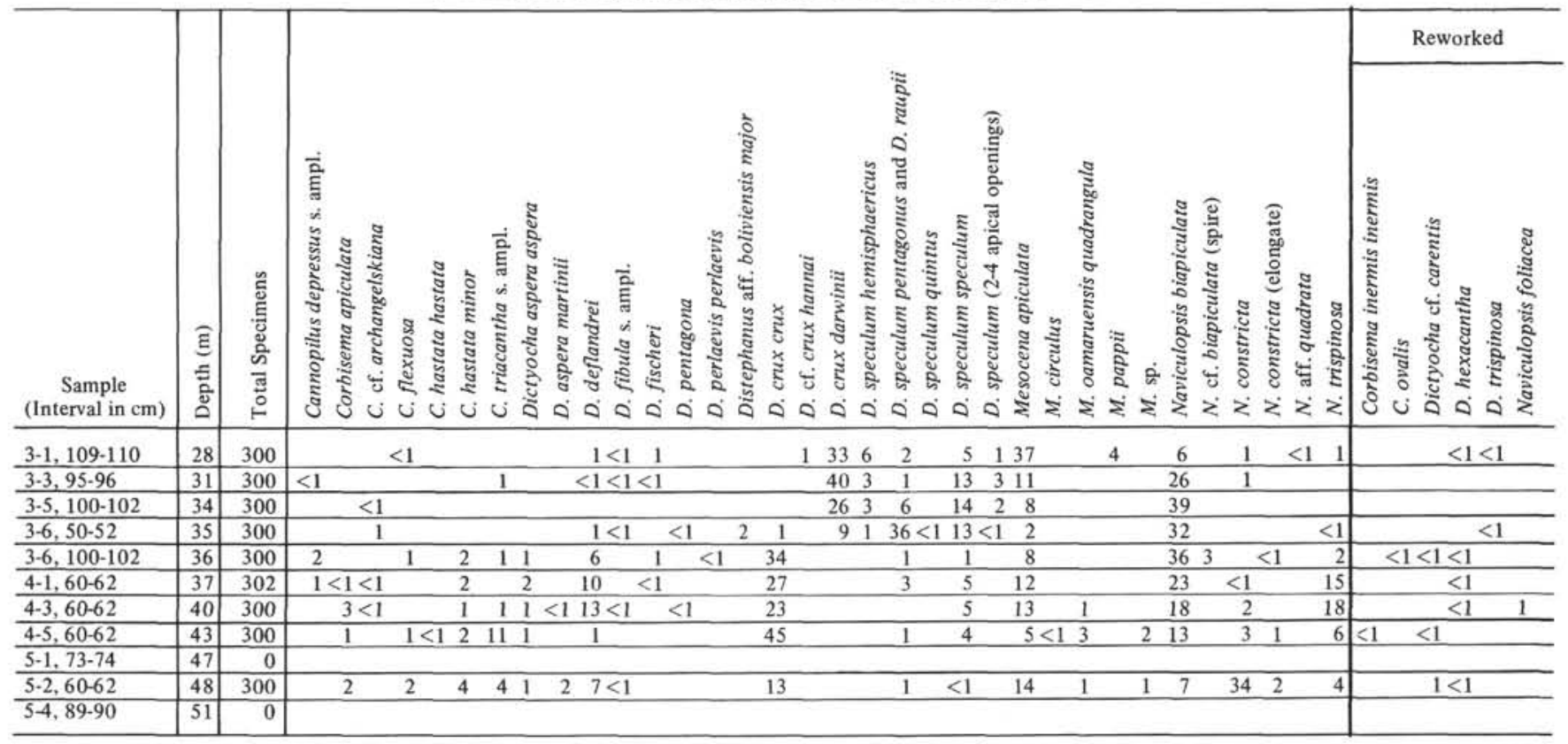

Note: Samples from Cores 3B and 4B are assigned to the upper Oligocene Naviculopsis biapiculata Zone. The Core 5B sample is assigned to the upper Eocene Dictyocha deflandrei Zone, Naviculopsis trispinosa Subzone.

tains a great abundance of specimens but only a few species: Chiasmolithus sp. cf. C. altus (rims), Coccolithus pelagicus, Cyclicargolithus sp. cf. C. floridanus, Reticulofenestra pseudoumbilica (closed and open centers), Reticulofenestra spp. (small). The Chiasmolithus and Cyclicargolithus specimens are probably reworked from
Oligocene strata, for age-equivalent Oligocene diatoms and silicoflagellates such as Stictodiscus gelidus and Naviculopsis biapiculata are also present.

A few specimens of Coccolithus miopelagicus and Sphenolithus sp. cf. S. abies in a Reticulofenestra ooze of Sample $329-26-2,50-51 \mathrm{~cm}(333 \mathrm{~m})$, suggest a possible 
TABLE 4

Silicoflagellates in Upper Miocene to Pleistocene Samples from Sites 327, 328, and 331 Recorded as Percents

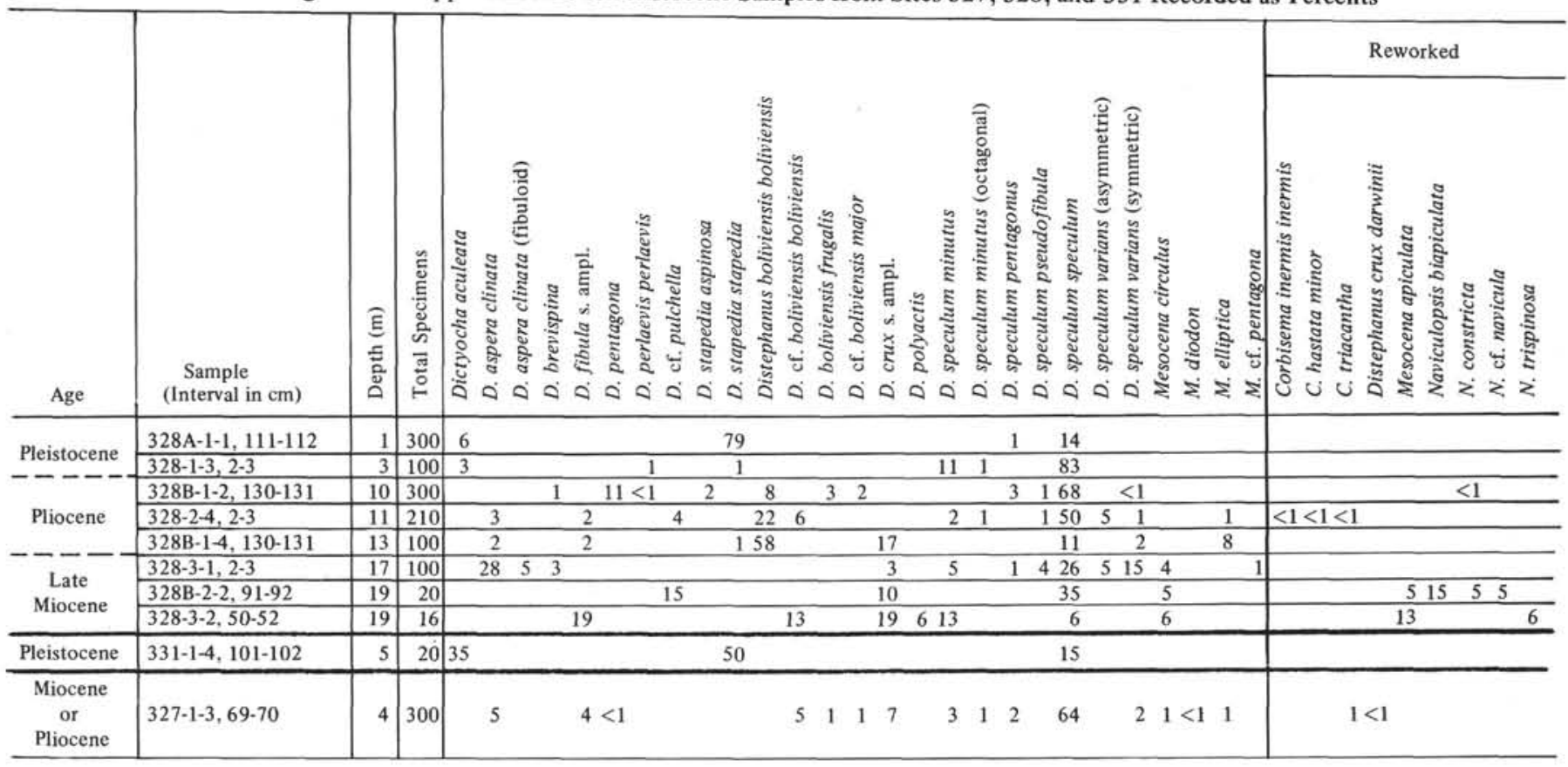

middle Miocene age because Cyclicargolithus floridanus is absent. Reworking introduced Chiasmolithus rims and late Paleocene $C$. bidens and Zygrhablithus sp. cf. Z. bijugatus that are abundant in deeper strata at Site 329. Specimens of Cyclicargolithus abisectus, C. sp. cf. C. floridanus, and Discoaster divaricatus in Sample 329-27$1,60-61 \mathrm{~cm}(361 \mathrm{~m})$ suggest an early Miocene age. The highest Chiasmolithus altus ooze in Sample 329-30-2, $117-118 \mathrm{~cm}(410 \mathrm{~m})$, considered Oligocene in age, contains abundant Coccolithus pelagicus s. ampl., a few Dictyococcites bisectus and D. scrippsae, but lacks warmwater taxa of the genera Discoaster, Helicopontosphaera, and Sphenolithus, which would further aid in correlation.

The two deepest Cenozoic samples available are probably from the upper Paleocene Discoaster multiradiatus Zone. Sample 329-32-4, 33-35 cm (447 m), contains abundant Zygrhablithus sp. cf. Z. bijugatus (?sỳn. Semihololithus kerabyi), Chiasmolithus bidens, and common to sparse Coccolithus sp. cf. C. magnicrassus, Discoaster multiradiatus, D. nobilis, and Thoracosphaera sp. A more typical Paleocene assemblage occurs in 329-33-4, 77-78 cm (459 m): Chiasmolithus bidens, Discoaster multiradiatus, Fasciculithus tympaniformis, Neochiastozygus distentus, N. junctus, Thoracosphaera sp., and Toweius eminens. The cold-water aspect of the assemblage is emphasized by a low Discoaster/Chiasmolithus ratio of $3 / 97$.

Miocene silicoflagellate distribution is summarized in Table 5.

\section{Site 330}

(lat $50^{\circ} 55.19^{\prime} \mathrm{S}$, long $46^{\circ} 53.00^{\prime} \mathrm{W}$, depth $2626 \mathrm{~m}$ )

No Cenozoic samples were obtained at this site on the eastern Falkland Plateau. Coring was begun at 129 meters subbottom to sample Mesozoic strata.

\section{Site 331}

(lat $37^{\circ} 53.00^{\prime} \mathrm{S}$, long $38^{\circ} 06.92^{\prime} \mathrm{W}$, depth $5067 \mathrm{~m}$ )

Site 331 in the Argentine Basin was aborted by bad mechanical and meterologic conditions. The two samples examined from near-surface sediment at the site are barren of coccoliths. A sparse silicoflagellate assemblage in Sample 331-1-4, 101-102 cm (5 m) contains Dictyocha aculeata, a Pleistocene guide species (Table 4).

\section{SILICOFLAGELLATE TAXONOMY}

Silicoflagellates present many taxonomic challenges for the biostratigrapher. Study of a single assemblage usually reveals considerable intraspecific variation. But lineages observed in stratigraphic sections commonly can be developed to help establish which forms are phenotypes and which are distinctive evolutionary entities.

Although a natural classification that permits reproducible correlation is the ultimate goal of stratigraphic taxonomy, much of the present generic and some species usage follows an artificial form-classification. According to present usage, the two major Cenozoic genera Dictyocha and Distephanus both seem to give rise to each other several times. For example, Dictyocha deflandrei gives rise to Distephanus crux darwinii in the Oligocene of Site 328, Distephanus boliviensis boliviensis produces Dictyocha pentagona in the Pliocene of Hole 328B, and Dictyocha pseudofibula of various workers arises from Distephanus speculum (see Schulz, 1928) or Distephanus speculum varians (this report). Therefore, better understanding of lineages at the species and subspecies level is needed. Establishing consistent usage and priority between names and the illustrated forms can be difficult, because original materials are commonly poorly dated and illustrated by single simple drawings that 
TABLE 5

Silicoflagellates in Miocene Samples From Site 329 Recorded as Percents

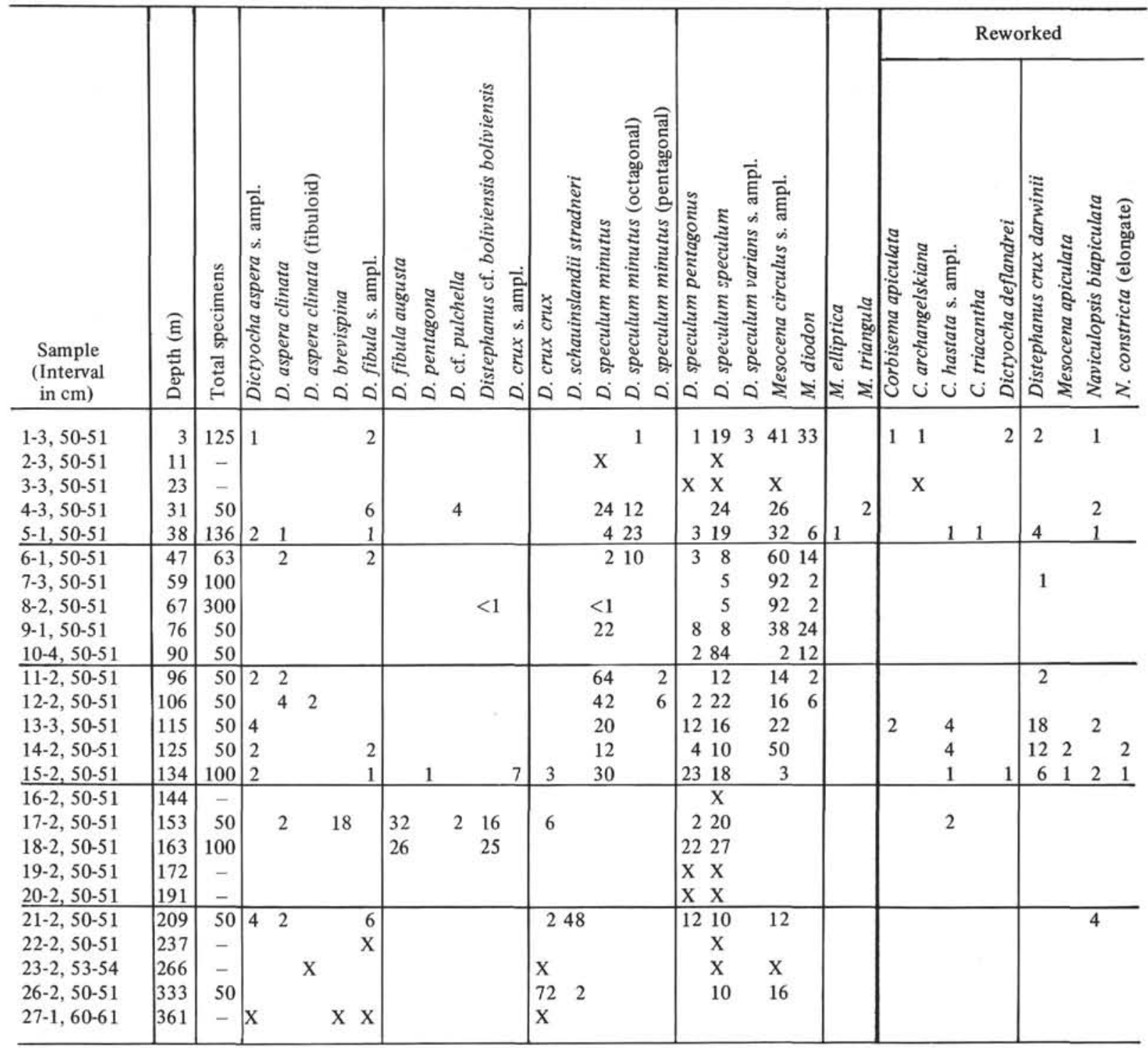

Note: The acmes of Mesocena circulus and M. diodon between 3 and 125 meters indicate the late Miocene Mesocena circulus Subzone of the Distephanus speculum speculum Zone (Bukry, 1975d). Deeper assemblages are not diagnostic of presently described zones. $\mathrm{X}=$ Taxa present in assemblage too sparse to validly count.

can be ambiguously interpreted and related to several similar forms.

Within major geometric form groups recognized at the species level (for example, D. speculum), stratigraphically or geographically restricted variations have been classified at the subspecies level (for example, $D$. speculum varians). Below the subspecies level, vernacular descriptive terms seem more appropriate than run-on linnean sequences, because a single subspecies name can be used to stand for a major set of morphologic parameters. Subspecies that are eventually found to be stratigraphically or ecologically limited and generally recognizable can later be elevated. See, for example, Corbisema flexuosa (Stradner) as reported in DSDP Volume 29 (Perch-Nielsen, 1975; Bukry, 1975d).
Species tabulated in the broad sense (s. ampl.) include forms not clearly assignable to an existing subspecies, commonly because specimens are tilted or broken.

\section{SYSTEMATIC PALEONTOLOGY}

Genus CANNOPILUS Haeckel, 1887

Cannopilus depressus (Ehrenberg)

Halicalyptra depressa Ehrenberg, 1854, pl. 18, fig. 111.

Cannopilus sphaericus Gemeinhardt, Bachmann and Keck, 1969, p. 205, pl. 2, left-upper figure.

Cannopilus sphaericus Gemeinhardt, Ling, 1972, p. 149, pl. 23, fig. 810.

Cannopilus depressus (Ehrenberg) Locker, 1974, p. 639, pl. 4, fig. 3.

Remarks: The structure of the type species of Cannopilus, C. hemisphaericus, leads me to believe that it is a member of Distephanus. 
Therefore, the name Cannopilus is retained for helmet-shaped silicoflagellates only as a convenience in this report. Because of the priority of the name Distephamus, revision of nomenclature should be considered.

Genus CORBISEMA Hanna, 1928

Corbisema apiculata (Lemmermann)

Dictyocha triacantha var. apiculata Lemmermann, 1901, p. 259, pl. 10, fig. 19, 20.

Corbisema apiculata (Lemmermann), Frenguelli, 1940 (in part), fig. $12 \mathrm{~h}$.

Corbisema triacantha (Ehrenberg), Frenguelli, 1940 (in part), fig. 12g.

Corbisema apiculata (Lemmermann), Ling, 1972, p. 151, pl. 23, fig. 13-17.

\section{Corbisema archangelskiana (Schulz)}

Dictyocha triacantha archangelskiana Schulz, 1928, p. 250, fig. 33a-c, 77 (not fig. 78).

Corbisema archangelskiana (Schulz), Perch-Nielsen, 1975, p. 685, pl. 3 , fig. 17,22 .

Remarks: Specimens with elongate portals, no spines at the apices, and no apical plate are included. Figure 78 of Schulz (1928) has short spines and a broader apical structure

Corbisema disymmetrica angulata n. subsp.

(Plate 1, Figures 1-4)

Dictyocha navicula Ehrenberg, Schulz, 1928 (in part), p. 243, fig. 16a. Corbisema apiculata (Lemm.) forma naviculoidea, Frenguelli, 1940, p. 62, fig. 12i. (Invalid by ICBN Art. 32, par. 1, see Loeblich et al., 1968).

?Corbisema inermis ssp. disymmetrica Dumitrica, 1973 (in part), p. 846 , pl. 12 , fig. 3 .

Dictyocha navicula Ehrenberg, Muhina, 1974, p. 854, pl. 2, fig. 13.

Description: Corbisema disymmetrica angulata is constructed as a large, bilaterally symmetric, boat-shaped basal ring with a slightly arched apical bar across the minor axis of the basal ring. The ends of the basal ring form a rounded or straight angle of $90^{\circ}$ or less that is symmetric about the major axis. Well-preserved specimens may have a delicate septum at the apex of the angle. The sides of the basal ring may be parallel near the apical bar juncture, but are typically slightly indented toward the juncture. The apical bar is slightly narrower than the ring. The ratio of the major to minor axis ranges from 1.7 to 2.2 .

Remarks: Corbisema disymmetrica angulata is distinguished from $C$. disymmetrica communis by having angular instead of rounded apices on the basal ring. It is distinguished from $C$. disymmetrica disymmetrica by its more elongate form and lack of crenulate surface texture. The Falkland Plateau specimens of $C$. disymmetrica angulata are generally less elongate than the forms in synonomy (major/minor axis $=1.7$ to 2.4 ).

Occurrence: Corbisema disymmetrica angulata appears higher in the upper Paleocene section at DSDP Hole 327A than the other subspecies of $C$. disymmetrica. The specimens in synonymy are from the Paleocene of the Indian Ocean, Tasman Sea, and Denmark. The known range is upper Paleocene.

Size: Major axis 80-120 $\mu \mathrm{m}$; holotype $100 \mu \mathrm{m}$.

Holotype: USNM 221574 (Plate 1, Figure 4).

Paratypes: USNM 221575 to 221577.

Type locality: Falkland Plateau, South Atlantic Ocean, Sample $327 \mathrm{~A}-5-4,100-102 \mathrm{~cm}(48 \mathrm{~m})$,

\section{Corbisema disymmetrica communis n. subsp.}

(Plate 1, Figures 5-9)

?Dictyocha apiculata (Lemm.) var, inermis (Lemm.), Deflandre, 1941 (in part), p. 102, fig. 22.

Dictyocha navicula Ehrenberg, Glezer, 1966, p. 251, pl. 9, fig. 4, 5; text-fig. 6(6).

Description: Corbisema disymmetrica communis is a small to medium-sized, basically oblong-shaped skeleton. The apices of the basal ring are in the form of a smoothly rounded, continuous curve that is symmetric about the major axis. The sides of the basal ring are parallel or indented toward the juncture of the apical bar. The apical bar is arched above the basal ring and only slightly narrower in diameter than the basal ring. Basal-ring pikes are usually present at the apical-bar juncture. The major to minor axis ratio ranges from 1.7 to 2.3 .
Remarks: Corbisema disymmetrica communis is distinguished from C. disymmetrica angulata by its regular curved apices and smaller size. It is distinguished from $C$. disymmetrica disymmetrica by its lack of crenulate surface texture. Most of the specimens of $C$. disymmetrica communis in Hole 327A have major to minor axis ratios of about 1.7 ; they are narrower in the basal assemblage at Sample 327A-8-3, 43-44 $\mathrm{cm}(74 \mathrm{~m})$, ratios being about 2.3 . Two specimens with a radial spine or pike at the basal-ring apex were found, but the internal margin of the basal ring is a smooth curve.

Occurrence: Corbisema disymmetrica communis is the most abundant and consistently present subspecies of $C$. disymmetrica in the upper Paleocene in Hole 327A. Glezer's specimen is from the lower Eocene of the Ural Mountains, USSR.

Size: Major axis $50-80 \mu \mathrm{m}$; holotype $58 \mu \mathrm{m}$.

Holotype: USNM 221578 (Plate 1, Figure 8).

Paratypes: USNM 221579 to 221582.

Type locality: Falkland Plateau, South Atlantic Ocean, Sample $327 \mathrm{~A}-6-6,130-132 \mathrm{~cm}(61 \mathrm{~m})$.

\section{Corbisema disymmetrica disymmetrica (Dumitrica) n. comb.}

(Plate 1, Figures 10-12)

not Dictyocha navicula Ehrenberg, 1839, p. 129.

not Dictyocha navicula Ehrenberg, Schulz, 1928, p. 243, fig. 16a, b. ?Dictyocha apiculata (Lemm.) var. inermis (Lemm.), Deflandre, 1941 (in part), p. 102, fig. 20, 21.

Corbisema inermis ssp. disymmetrica Dumitrica, 1973 (in part), p. 846 ,

pl. 12, fig. 1, 2, 4-6; pl. 13, fig. 1-8.

Corbisema inermis disymmetrica Dumitrica, Perch-Nielsen, 1975, $\mathrm{p}$ 685 , pl. 8, fig. 1, 2.

Remarks: Corbisema disymmetrica disymmetrica ranges in shape from subcircular to oblong to rounded square. The robust and crenulate nature of the basal ring, apical bar, and accessory projections easily distinguish it from other subspecies of $C$. disymmetrica. And, its major and minor axis are more nearly equal.

Corbisema disymmetrica disymmetrica occurs rarely throughout the upper Paleocene section in Hole 327A. These specimens are well preserved and reveal that the regular crenulations are created by regularly spaced cycles of nodes. Because $C$. inermis crenulata is not present in Hole 327A, the bipolar form is considered to represent an evolutionary development that warrants status at the species level. The individual figured in plate 13, figure 5, of Dumitrica (1973) is herein designated the lectotype specimen of Corbisema disymmetrica disymmetrica.

\section{Corbisema falklandensis n. sp.}

(Plate 2, Figures 1-15)

Description: Corbisema falklandensis is pear-shaped in plan view. The apical structure has a triangular apical plate supported by arched struts that are ribbon-like or lamelliform. Similar arching lamelliform projections occupy the positions of basal pikes. These flare and terminate irregularly. A short radial spine or pike occurs at the apex of the basal ring, which has a septum at that point. There are no radial spines at the other rounded apices.

Remarks: Corbisema falklandensis is distinguished from other species of Corbisema by having only a single apical spine and by its isosceles outline and lamelliform basal pikes. It is distinguished from the isosceles $C$. hastata group by the nearly T-shaped form of its apical structure, the lack of spines, and the presence of an apical plate.

Occurrence: Corbisema falklandensis occurs rarely through the upper Paleocene in Hole 327A.

Size: Major axis $45-70 \mu \mathrm{m}$; holotype $49 \mu \mathrm{m}$.

Holotype: USNM 221583 (Plate 2, Figures 8, 9)

Paratypes: USNM 221584 to 221592.

Type locality: Falkland Plateau, South Atlantic Ocean, Sample $327 \mathrm{~A}-6-1,9-10 \mathrm{~cm}(52 \mathrm{~m})$.

\section{Corbisema flexuosa (Stradner)}

Corbisema triacantha flexuosa Stradner, 1961, p. 89, pl. 1, fig. 1-8. Corbisema flexuosa (Stradner) Perch-Nielsen, 1975, p. 685, pl. 3, fig. 10.

Corbisema geometrica Hanna

Corbisema geometrica Hanna, 1928, p. 261, pl. 41, fig. 1, 2.

Corbisema geometrica Hanna, Perch-Nielsen, 1975, p. 685, pl. 2, figs. $1-6,8$. 
Corbisema geometrica geometrica Hanna, Bukry, 1975d (in part), p. 853 , pl. 1, fig. 7.

Remarks: This large, rounded to lobed species has a central plate and lacks spines; it is most abundant in the Upper Cretaceous. Similar large forms that lack a central plate and that persist after the disappearance of Corbisema geometrica are assigned to $C$. inermis inermis.

\section{Corbisema glezerae n. sp.}

(Plate 3, Figures 1-7)

?Dictyocha triacantha Ehrenberg, Schulz, 1928 (in part), p. 247, fig. 24.

Dictyocha triacantha Ehrenberg var. triacantha f. triacantha Glezer, 1966 (in part), p. 243, pl. 4, fig. 3-6.

Description: Corbisema glezerae is a large, robust, symmetric species having an equilateral triangular-shaped basal ring that is straight sided or slightly convex. The radial spines are medium to long and are septate. The struts are symmetric and have the same diameter as the sides of the basal ring. Large basal pikes extend downward, perpendicular to the plane of the basal ring, below the strut-ring juncture.

Remarks: The large size, septate apices, and very large pikes distinguish Corbisema glezerae from the Corbisema triacantha group. The large, robust, tapering spines and pikes, and the proportion of tube diameter to portal area serve to distinguish C. glezerae from similar equilateral species such as C. apiculata or Dictyocha elata (see Glezer, 1966).

Occurrence: Corbisema glezerae occurs throughout the upper Paleocene in Hole 327A. Glezer's specimens are from the Paleocene and Eocene of the USSR. I have not seen this species in Oligocene or younger assemblages.

Size: Internal diameter 25-35 $\mu \mathrm{m}$; holotype $29 \mu \mathrm{m}$.

Holotype: USNM 221593 (Plate 3, Figure 3).

Paratypes: USNM 221594 to 221598.

Type locality: Falkland Plateau, South Atlantic Ocean, Sample $327 \mathrm{~A}-6-3,100-102 \mathrm{~cm}(56 \mathrm{~m})$.

\section{Corbisema hastata cunicula n. subsp.}

(Plate 3, Figures 8-15)

Description: Corbisema hastata cunicula has a partly rounded isosceles basal ring and moderate to long spines. The two long sides of the basal ring are convex and the short side essentially straight. The length of the spines is typically only slightly less than the major axis of the basal ring; they are never perpendicular to the short side of the basal ring. The apical struts are plain and only slightly asymmetric.

Remarks: Corbisema hastata cunicula is distinguished from other subspecies of $C$. hastata by the unscalloped long sides of the basal ring, smaller basal ring, and proportionally longer spines. Other subspecies may have radial spines perpendicular to the short side of the basal ring. No lamelliform specimens occur in Hole 327A (see Dictyocha lamellifera group of Glezer, 1966).

Occurrence: Corbisema hastata cunicula first appears within the upper Paleocene section in Hole 327A and is most abundant in the upper part of the section.

Size: Internal diameter 15-22 $\mu \mathrm{m}$; holotype $17 \mu \mathrm{m}$

Holotype: USNM 221599 (Plate 3, Figure 15).

Paratypes: USNM 221600 to 221606.

Type locality: Falkland Plateau, South Atlantic Ocean, Sample $327 \mathrm{~A}-6-6,130-132 \mathrm{~cm}(61 \mathrm{~m})$.

\section{Corbisema hastata globulata n. subsp.} (Plate 4, Figures 1-8)

Dictyocha triacantha var. hastata Lemmermann, Glezer, 1966 (in part), p. 248 , pl. 7 , fig. 1.

Description: Corbisema hastata globulata is a short-spined subspecies having an isosceles basal ring that shows internal or external scalloping on all three sides at the strut-ring junctures.

Remarks: The lobate, short-spined appearance of Corbisema hastata globulata distinguishes it from all other isosceles Corbisema specimens classified in the $C$. hastata group.

Occurrence: Corbisema hastata globulata occurs throughout the upper Paleocene section in Hole 327A.

Size: Internal diameter 15-25 $\mu \mathrm{m}$; holotype $20 \mu \mathrm{m}$.

Holotype: USNM 221607 (Plate 4, Figure 2).

Paratypes: USNM 221608 to 221614.

Type locality: Falkland Plateau, South Atlantic Ocean, Sample $327 \mathrm{~A}-5-4,100-102 \mathrm{~cm}$ (48 m).
Corbisema hastata hastata (Lemmermann)

(Plate 4, Figures 9-16)

Dictyocha triacantha hastata Lemmermann, 1901, p. 259, pl. 10, fig. $16,17$.

Remarks: The basal ring of Corbisema hastata hastata is isosceles in plan. On most specimens the short side is indented and the long sides scalloped. As the relative proportion of structural components is highly variable, a group of forms is illustrated here. C. hastata hastata is abundant in Paleocene assemblages.

\section{Corbisema hastata minor (Schulz)}

Dictyocha triacantha apiculata minor Schulz, 1928, p. 249, fig. 29 b. Corbisema hastata minor (Schulz), Bukry, 1975d, p. 854, pl. 1, fig. 10.

\section{Corbisema inermis inermis (Lemmermann)}

(Plate 5, Figures 1-3)

Dictyocha triacantha inermis Lemmermann, 1901, p. 259, pl. 10, fig. 21.

Dictyocha triacantha inermis Lemmermann, Schulz, 1928, p. 248, fig. $30 \mathrm{a}, \mathrm{b}$.

Corbisema geometrica Hanna, Ling, 1972 (in part), p. 154, pl. 24, figs. 3,4 .

Remarks: This large, rounded to triangular species lacks an apical plate and spines. Whereas its size and proportions are similar to Corbisema geometrica, it is distinguished by the absence of an apical plate. It occurs consistently in the Paleocene in Hole 327A, above the range of the bascially Upper Cretaceous species C. geometrica. Several specimens of an isosceles variant of $C$. inermis inermis in Hole 327A have one rounded and two angular apices.

Drawings of specimens of this subspecies portraying smooth (Lemmermann, 1901) or slightly irregular surfaces (Glezer, 1966) are believed to represent reticulate texture, not the more pronounced crenulate texture (Bukry, 1976).

Corbisema inermis crenulata $n$. subsp.

Corbisema inermis (Lemmermann) Dumitrica, 1973, p. 845, pl. 12, fig. 7-9.

Description: Corbisema inermis crenulata has a rounded triangular basal ring. Three apical struts are symmetrically arrayed and meet simply with no apical plate. Basal pikes may be present at or near the ring-strut junctures. The struts are narrower than the basal ring and lack its distinctive crenulate texture, formed by regular cycles of surface nodes.

Remarks: Corbisema inermis crenulata is distinguished from C. inermis inermis by its proportionately thicker basal ring and crenulate surface texture. Whereas the crenulate body ring shows a genetic relation between $C$. inermis crenulata and $C$. disymmetrica disymmetrica (Dumitrica, 1973), C. disymmetrica disymmetrica has an apical bar of comparable size and crenulation to the basal ring, which $C$. inermis crenulata lacks. This structural distinction and the occurrence of only C. disymmetrica disymmetrica in the upper Paleocene in Hole $327 \mathrm{~A}$ indicates that these two crenulate silicoflagellates can be considered as separate taxa.

Occurrence: Corbisema inermis crenulata is known from the Paleocene of the southwestern Pacific Ocean at DSDP 208.

Size: External diameter 93 to $109 \mu \mathrm{m}$; holotype $109 \mu \mathrm{m}$.

Holotype: Plate 12, Figure 9 of Dumitrica, 1973.

Paratypes: Plate 12, Figures 7, 8 of Dumitrica, 1973. m).

Corbisema inermis minor (Glezer) n. comb.
(Plate 5, Figures 4-7)

Dictyocha triacantha var. inermis f. minor Glezer, 1966, p. 247, pl. 8 , fig. $3-5$; pl. 31, fig. 7.

Remarks: This consistently small, rounded subspecies has an elevated apical structure. The specimens from Hole 327A match those described from the USSR (Glezer, 1966).

Corbisema lateradiata (Schulz)

Dictyocha triacantha apiculata late-radiata Schulz, 1928, p. 281, fig. 73 .

Corbisema geometrica Hanna, Ling 1972 (in part), p. 154, pl. 24, fig. 2. Corbisema lateradiata (Schulz) Perch-Nielsen, 1975, p. 686, pl. 2, fig. $7,10,11,17,18$. 
Corbisema geometrica lateradiata (Schulz) Bukry, 1975d, p. 853, pl. 1, fig. 8.

Corbisema geometrica Hanna var. apiculata Jousé, Hajós, 1975, p. 938 , pl. 15, fig. 2, 3, 5 .

\section{Corbisema neoparallela n. sp.}

(Plate 5, Figures 8-13)

Description: Corbisema neoparallela has a rounded, polygonal basal ring with 12 sides. The apical structure is a symmetric triad of struts with no apical plate. The three portals are six-sided. The three radial spines are very short.

Remarks: Corbisema neoparallela is distinguished from Corbisema parallela the only other species that has a compact multisided outline by having three more sides, radial spines, and by lacking an apical plate.

Occurrence: Corbisema neoparallela occurs rarely and in only the upper part of the upper Paleocene section in Hole 327A.

Size: Diameter, axial, $25-40 \mu \mathrm{m}$; holotype $28 \mu \mathrm{m}$.

Holotype: USNM 221615 (Plate 5, Figure 9).

Paratypes: USNM 221616 to 221619.

Type locality: Falkland Plateau, South Atlantic Ocean, Sample $327 \mathrm{~A}-5-2,100-102 \mathrm{~cm}(45 \mathrm{~m})$.

\section{Corbisemn ovalis Perch-Nielsen}

?Dictyocha triacantha var. archangelskiana Schulz, 1928 (in part), p. 250 , fig. 78 .

Corbisema ovalis Perch-Nielsen, in press, pl. 1, fig. 12, 13.

\section{Corbisema parallela Hajós}

Corbisema parallela Hajós, 1975, p. 938, pl. 15, fig. 4, 6, 7.

Remarks: This species differs from Corbisema neoparallela by its larger size, apical plate, and lack of spines. The structural relation between $C$. parallela and $C$. neoparallela illustrates the general evolutionary trends in Corbisema: the loss of the apical plate, decrease in size, and increased dominance of spined forms between the Cretaceous and Miocene.

\section{Corbisema triacantha (Ehrenberg)}

Dictyocha triacantha Ehrenberg 1844a, p. 80.

Corbisema triacantha (Ehrenberg) Perch-Nielsen, 1975, p. 686, pl. 3, fig. $11,15,16$.

Remarks: Some workers include a range of forms in this species. General usage for this report is to include small to moderate-sized long-spined specimens that have a basal ring in the form of an equilateral triangle. Basal pikes are missing or indistinct.

\section{DICTYOCHA Ehrenberg, 1837}

Dictyocha aculeata (Lemmermann)

Dictyocha fibula var. aculeata Lemmermann, 1901, p. 261, pl. 11, fig. $1,2$.

Dictyocha epiodon (Ehrenberg) Bukry and Foster, 1973, p. 826, pl. 2 fig. 7,8 .

Dictyocha aculeata (Lemmermann), Perch-Nielsen, 1975, p. 686, pl. 5, fig. 3,4 .

\section{Dictyocha aspera aspera (Lemmermann)}

Dictyocha fibula aspera Lemmermann, 1901, p. 260, pl. 10, fig. 27, 28 Dictyocha aspera (Lemmermann), Perch-Nielsen, 1975, p. 686, pl. 4, fig. $9, ? 10,15$

\section{Dictyocha aspera clinata Bukry}

Dictyocha sp. A. Ling, 1975 , p. 772 , pl. 1, fig. 20, 21.

Dictyocha aspera clinata Bukry, 1975c, p. 695, pl. 1, fig. 1-5.

\section{Dictyocha aspera martinii Bukry}

Dictyocha frenguellii Deflandre, Perch-Nielsen, 1975, p. 686, pl. 4, fig. 14,17 ; pl. 5, fig. 1 .

Dictyocha aspera martinii Bukry, 1975d, p. 854, pl. 2, fig. 5-8.

Remarks: Dictyocha frenguellii of Perch-Nielsen from DSDP Leg 29 have an apical bar transverse to a distinctly elongate basal ring and the adjoining pair of radial spines. Deflandre (1950) shows Dictyocha frenguellii to have equal to slightly subequal dimensions for the basal ring and spines; the apical structure is not a bar. A robust specimen of D. frenguellii illustrated from the Eocene of USSR (Glezer, 1966) shows the modified nature of the apical structure that distinguishes it from Dictyocha aspera martinii. Structurally, Deflandre's drawings are more similar to the photographs of Oligocene Dictyocha fischeri (see Bukry, 1975 d, pl. 3, fig. 10, 11) from Leg 29, but $D$. frenguellii has basal pikes.

\section{Dictyocha brevispina (Lemmermann)}

Dictyocha fibula var. brevispina Lemmermann, 1901, p. 260.

Dictyocha fibula var. aspera f. rhombica Schulz, 1928, p. 253, fig. 37.

Dictyocha ausonia Deflandre, Uchio, 1974 (in part), p. 247, pl. 2, fig. $10,11,15$, (not 14).

\section{Dictyocha carentis (Glezer)}

Dictyocha frenguellii var. carentis f. carentis Glezer, 1964, p. 52, pl. 1, fig. 12-14

Dictyocha frenguellii var. carentis f. carentis Glezer, 1966, p. 258, pl. 9, fig. 8 , 10-13; pl. 33, fig. $1,2$.

Dictyocha $\mathrm{cf}$. D. carentis (Glezer) Perch-Nielsen, 1975 (in part), p. 686 , pl. 4, fig. 1, 6 .

\section{Dictyocha sp. cf. D. elongata Glezer}

Dictyocha elongata Glezer, 1960, p. 131, pl. 2, fig. 16-20.

Dictyocha elongata Glezer, Perch-Nielsen, in press, pl. 1, fig. 2.

\section{Dictyocha deflandrei Frenguelli ex Glezer}

Dictyocha deflandrei Frenguelli, 1940 (in part), p. 65, fig. 14a, c. d, ?e, $\mathrm{f}$, (not $\mathrm{b}$ and $\mathrm{g}$ ).

Dictyocha deflandrei Frenguelli ex Glezer, 1966, p. 244.

Dictyocha medusa Haeckel, Perch-Nielsen, 1975 (in part), p. 686, pl. 4, fig. 5 ; pl. 15, fig. 5-7.

Dictyocha pentagona (Schulz), Perch-Nielsen, 1975, p. 687, pl. 5, fig. 11 ; pl. 15, fig. 4

Dictyocha deflandrei Frenguelli ex Glezer, Bukry, 1975d, p. 854, pl. 2, fig. 9-13.

\section{Dictyocha fibula Ehrenberg}

Dictyocha fibula Ehrenberg 1839, fide Loeblich et al., 1968, p. 90, pl. 9, fig. 7-12.

Dictyocha fibula augusta n. subsp.

(Plate 6, Figures 1-5)

?Dictyocha fibula Ehrenberg, Ling, 1973, p. 751, pl. 1, fig. 9, 10. Dictyocha fibula fibula Ehrenberg, Bukry, 1975d (in part), p. 854, pl. 3 , fig. 2.

Dictyocha cf. D. perlaevis Frenguelli, Perch-Nielsen, 1975 (in part), p. 687 , pl. 5, fig. 16, 17.

Description: Dictyocha fibula augusta is a large subspecies having an angular basal ring, usually in the form of an elongate rhomb. Basal pikes are small, rounded, and distinctly offset from the strut-ring junctures. The apical bar is parallel or slightly subparallel to the major axis, and the strut attachment to the basal ring is slightly asymmetric. The spines are long, the major-axis spines being only slightly shorter than the maximum internal diameter of the basal ring. The solid walls of the tubular elements are thicker with respect to the tubular canal than other Neogene species of Dictyocha.

Remarks: Dictyocha fibula augusta is distinguished from the Dictyocha perlaevis group by its rhomboid basal ring and asymmetric strut placement. It is distinguished from Dictyocha epiodon of Locker (1974) by its more regular form, absence of peripherally directed pikes, and the essentially uncanted alignment of the apical bar that is distinctly longer relative to the major axis of the basal ring (30\% to $46 \%$ compared with only $22 \%$ and $23 \%$ ). It is distinguished from other members of the Dictyocha fibula group by its large size, long spines, and narrow canals in the tubular elements. Ehrenberg's first figured specimen of Dictyocha fibula, from seawater at Christiana, Norway (Loeblich et al., 1968, pl. 9, fig. 7), closely resembles D. fibula augusta. The stratigraphic dichotomy in occurrence between late Miocene and modern plankton is the only clearcut distinction. However, both of these forms are atypical of the series of specimens illustrated by Ehrenberg (1854) as Dictyocha fibula. That series of specimens with rounded outline and moderate to short spines is believed to define Ehrenberg's central species concept for Dictyocha fibula fibula (see 
Ehrenberg, 1854; pl. 28, fig. 54a, c, 55; pl. 19, fig. 43; pl. 20, fig. 45; pl. 22, A, center left; pl. 33, 16 fig. 10). Locker's (1974) subsequent designation of an ambiguous type specimen for $D$. fibula, which is seemingly antithetic to Ehrenberg's concept, is not followed in this report.

Size: Major axis, basal ring 30-45 $\mu \mathrm{m}$, holotype $38 \mu \mathrm{m}$.

Holotype: USNM 221620 (Plate 6, Figures 1-3).

Paratype: USNM 221621.

Type locality: Falkland Plateau, South Atlantic Ocean, Sample 329$18-2,50-51 \mathrm{~cm}(163 \mathrm{~m})$.

\section{Dictyocha fischeri n. sp.}

Dictyocha frenguellii Deflandre, Ciesielski, 1975, p. 658, pl. 6, fig. 3-9. Dictyocha frenguellii Deflandre, Bukry, 1975b, pl. 1, fig. 11, 12.

Dictyocha cf. D. frenguellii Deflandre, Perch-Nielsen, 1975, p. 686, pl. 5 , fig. $7,8$.

Dictyocha frenguellii Deflandre, Bukry, 1975d, p. 855, pl. 3, fig. 10, 11.

Description: Dictyocha fischeri has a slightly rounded, square basal ring that lacks basal pikes. The spines are moderately long and are nonseptate. The apical structure is a modified apical plate or expanded strut junction that is usually square in outline. The four struts are equant and join the basal ring symmetrically; each strut has a distal process that extends beyond the basal ring and may be as long as the spines.

Remarks: Dictyocha fischeri is distinguished from $D$. frenguellii by the absence of basal pikes and by its more equant form. It is distinguished from $D$. deflandrei, its probable ancestor, by the elevated distal processes of its struts.

Occurrence: Dictyocha fischeri occurs in the lower or upper Oligocene of the Southern Ocean at Sites 274, 278, and 328. It is a guide fossil for the Dictyocha fischeri Subzone of the Dictyocha deflandrei Zone (Bukry, 1975d). The D. fischeri Subzone is a new name for the $D$. frenguellii Subzone (Bukry, 1975d) required by the recognition of the taxonomic and stratigraphic distinction of $D$. fischeri from $D$. frenguellii.

Size: Internal diameter 15-25 $\mu \mathrm{m}$.

Holotype: Plate 1, figures 11, 12 of Bukry (1975b).

Type locality: Southern Ocean, Sample 274-21-5, $51 \mathrm{~cm}(197 \mathrm{~m})$.

\section{Dictyocha frenguellii Deflandre}

Dictyocha frenguellii Deflandre, 1950, p. 194, fig. 188-193.

Remarks: See remarks for Dictyocha aspera martinii and D. fischeri.

\section{Dictyocha hexacantha Schulz}

Dictyocha hexacantha Schulz, 1928, p. 255, fig. 43.

Dictyocha hexacantha Schulz, Bukry 1975d, p. 855, pl. 4, fig. 1, 2.

\section{Dictyocha pentagona (Schulz)}

Dictyocha fibula vvar. pentagona Schulz, 1928, p. 255, fig. 41a, b.

Remarks: The long Paleocene to Quaternary range reported for this supposed taxon suggests it could be a polyphyletic form category. Certain specimens from Leg 36 support this possibility. A specimen having the form of Dictyocha pentagona, but bearing a spire and having the same size and proportions as associated D. stapedia stapedia, is included in the count for that subspecies at Sample 328A-1-1, 111-112 $\mathrm{cm}(1 \mathrm{~m})$. The specimens of $D$. pentagona tabulated for 328B-1-2, 130 $131 \mathrm{~cm}(10 \mathrm{~m})$ are large and robust and match the associated specimens of Distephanus boliviensis boliviensis in size, surface texture, and proportions. This implies two different sources for silicoflagellate specimens having the $D$. pentagona geometry at Site 328 .

Holocene Dictyocha fibula pentagonalis Aurivillius (of Loeblich et al., 1968) has the $D$. pentagona geometry, but also has a spire and lacks basal pikes. a peculiar combination for that epoch because other dominant Dictyocha species have basal pikes whether they have a spire or not. Uchio (1974) illustrated a suite of upper Miocene specimens attributed to $D$. fibula pentagonalis that lacks spires but has basal pikes. Schulz illustrated his Dictyocha pentagona from the Paleocene without pikes (probably derived from $D$. precarentis) and a second, scalloped specimen with pikes from the Holocene (probably derived from $D$. perlaevis perlaevis). Irregular specimens of $D$. pentagona dominated a plexus of aberrant forms produced by a laboratory clone of Dictyocha fibula s. ampl. (Van Valkenburg and Norris, 1970). Therefore, the status of Dictyocha pentagona as a form category should be recog. nized. On a local basis it may be stratigraphically useful, but it would be misleading for transoceanic correlation.
Dictyocha perlaevis perlaevis Frenguelli

Dictyocha perlaevis Frenguelli, 1951, p. 279, fig. 4b, c. Dictyocha fibula perlaevis (Frenguelli) Bukry, 1975d, p. 855, pl. 3, fig. 5.

Dictyocha perlaevis perlaevis Frenguelli, Bukry, 1976, p. 724, pl. 2, fig. 4,5 .

Dictyocha precarentis n. sp.

(Plate 6, Figures 6-13; Plate 7, Figures 1-3)

not Dictyocha fibula Ehrenberg var. longispina Lemmermann, 1901, p. 260, pl. 10, fig. 26; fide Loeblich et al., 1968, p. 93, pl. 12, fig. 1. Corbisema deflandrei Frenguelli, Stradner, 1961 (in part), p. 89, pl. 1, fig. 13.

Description: Dictyocha precarentis has a regular basal ring that is straight-sided and nearly square in outline. The four medium to long spines at the corners are septate, equant, and axially aligned. The struts and apical bar are all approximately of equal length, but the bar may be slightly wider, typically by less than a factor of two. Basal pikes are rarely present and are small and indistinct. The portals are large relative to tube width.

Remarks: Dictyocha precarentis is distinguished from younger $D$. carentis by a much narrower apical bar; in $D$. carentis, the bar is broadened almost to a plate. The portals of $D$. precarentis are more angular and proportionally much larger than in $D$. carentis. $D$. precarentis is septate, suggesting evolution from early Corbisema. As Glezer $(1964,1966)$ did not illustrate this structure on other taxa that are septate, the status of this structure for $D$. carentis is not known.

Dictyocha precarentis is distinguished from Dictyocha fibula longispina, with which it bears closest resemblance in terms of proportions, by its septate radial spines and lack of distinct basal pikes. And the type specimen of $D$. fibula longispina is Holocene, from which no septate Dictyocha are known. The general form of the Holocene specimen is so similar to the Paleocene Falkland assemblages that they might be considered identical (Lemmermann listed the Paleocene as an additional occurrence for $D$. fibula longispina, according to Loeblich et al., 1968), but the accessory structures-septa and basal pikes-make the distinction possible.

Occurrence: Dictyocha precarentis is especially abundant in the lower part of the Paleocene in Hole 327A.

Size: Internal diameter 15-30 $\mu \mathrm{m}$; holotype $20 \mu \mathrm{m}$.

Holotype: USNM 221622 (Plate 6, Figures 10, 11).

Paratypes: USNM 221623 to 221630.

Type locality: Falkland Plateau, South Atlantic Ocean; Sample $327 \mathrm{~A}-8-3,43-44 \mathrm{~cm}$ (74 m).

Dictyocha pulchella Bukry
Dictyocha ausonia Deflandre, Uchio, 1974 (in part), p. 247, pl. 2, fig. 14.

Dictyocha pulchella Bukry, 1975c, p. 701, pl. 4, fig. 1-3.

Dictyocha spinosa (Deflandre)

Corbisema spinosa Deflandre, 1950, p. 193, fig. 178-182.

Dictyocha spinosa (Deflandre) Glezer, 1966, p. 238, pl. 10, fig. ?6, 7, 8 .

Dictyocha stapedia aspinosa Bukry

Dictyocha stapedia aspinosa Bukry, 1976, p. 724, pl. 2, fig. 6-9.

\section{Dictyocha stapedia stapedia Haeckel}

Dictyocha stapedia Haeckel, 1887, p. 1561, pl. 101, fig. 10-12.

Dictyocha stapedia stapedia Haeckel, Bukry, 1976, p. 724, pl. 3, fig. 1-7.

Genus DISTEPHANUS Stöhr, 1880

Distephanus boliviensis boliviensis (Frenguelli) (Plate 8, Figure 5)

Dictyocha boliviensis Frenguelli, 1940 (in part), p. 44, fig. 4a. Dictyocha boliviensis Frenguelli, 1951 (in part), p. 274, fig. 2c, h; fig. $4 \mathrm{~d}, \mathrm{f}$.

Distephanus boliviensis (Frenguelli) Bukry and Foster, 1973, p. 827, pl. 4 , fig. 1-3.

Remarks: Although separation of specimens with divided and subdivided apical rings appears to be an unnatural classification (see Bukry and Foster, 1973, pl. 7, fig. 2-4), the possible paleoecologic and stratigraphic use of such forms cannot be assessed for a rarely cited 
taxon until they are identified at more sites. Distephanus speculum populations are better known, and simple divided forms, such as $D$. speculum binoculus, are usually a low-frequency variation throughout the stratigraphic and geographic range of $D$. speculum. An exceptional series of assemblages from the early Miocene at Site 338 in the North Atlantic have D. speculum binoculus and D. speculum triommata more numerous than $D$. speculum speculum; the multiply divided $D$. speculum hemisphaericus is even more abundant there. The problem of distinguishing binoculoid variants, produced by various species of Distephanus, makes their usefulness suspect. The same problem exists for pentagonal variants of several essentially hexagonal taxa of Distephanus. The name Distephanus speculum pentagonus accommodates such forms for the Distephanus speculum group. Pentagonal variants of $D$. boliviensis boliviensis, $D$. boliviensis frugalis, or $D$. speculum minutus can be alternatively tabulated as $D$. speculum pentagonus (making it a polyphyletic form category), given a vernacular listing under the parent species, or, as Frenguelli (1951) implied, considered as undistinguished members of the parent species. Frenguelli's usage for pentagonal variants was followed for $D$. boliviensis boliviensis in this report. See remarks on Dictyocha pentagona.

Distephanus boliviensis frugalis Bukry

Distephanus boliviensis frugalis Bukry, 1975c, p. 697, pl. 2, fig. 2-7.

Distephanus boliviensis major (Frenguelli)

Dictyocha boliviensis Frenguelli, 1940 (in part), p. 44, fig. 4b-d.

Dictyocha boliviensis Frenguelli, 1951 (in part), p. 274, fig. 2d-f, g.; fig. $4 \mathrm{e}$

Dictyocha boliviensis var. major Frenguelli, 1951, p. 277, fig. 3a-c. Cannopilus major (Frenguelli) Bukry and Foster, 1973, p. 826, pl. 1, fig. 4-7; pl. 7, fig. 2.

\section{Distephanus crux crux (Ehrenberg)}

Dictyocha crux Ehrenberg, 1840, p. 207; Ehrenberg, 1854, pl. 18, fig. 56; pl. 20(1), fig. 46; pl. 33(15), fig. 9; pl. 33(16), fig. 9; pl. 33(17), fig. 5 .

Dictyocha speculum Ehrenberg, Frenguelli, 1951 (in part), p. 277, fig. $4 \mathrm{n}$.

Dictyocha crux Bachmann and Keck, 1969, p. 205, pl. 2, figures on lower left and lower right.

Distephanus crux spp. bispinosus Dumitrica, 1973, p. 850, pl. 6, fig. 3, 6,7 .

Distephanus crux (Ehrenberg), Dumitrica, 1973 (in part), p. 850, pl. 6, fig. 4, 5, 8, (not 11).

Distephanus mesophthalmus (Ehrenberg), Dumitrica, 1973, p. 850, pl. 6 , fig. 9, 10, 12, 13.

Distephanus crux (Ehrenberg), Locker, 1974 (in part), p. 637, pl. 3, fig. 8 , (not 10).

\section{Distephanus crux darwinii n. subsp.}

$$
\text { (Plate 7, Figures 4-13) }
$$

?Distephanus crux crux Glezer, 1966 (in part), p. 279, pl. 18, fig. 9. Description: Distephanus crux darwinii has a small rounded to angular square basal ring. The radial spines at the corners are nonseptate and medium to long. There are no basal pikes. The struts rise from the apical surface of the basal ring and flare slightly toward the center of the apical structure, which resembles an apical plate with a small rounded apical opening. Whereas the diameter of the apical area occupies a large fraction ( $30 \%$ to $50 \%$ ) of the basal-ring diameter, the small apical opening occupies only about $50 \%$ of the apical area

Remarks: Distephanus crux darwinii is distinguished from other quadrate species of Distephanus by the combination of large apical area, small apical opening, and lack of basal pikes. The apical area to basal ring proportions of Dictyocha crux Ehrenberg (1854) are in the range $27 \%$ to $33 \%$. Distephanus crux (Ehrenberg) of Locker (1974), including the types of Dictyocha staurodon Ehrenberg and D. mesophthalmus Ehrenberg, has distinct basal pikes and apical proportions that do not match $D$. crux darwinii. The Distephanus schauinslandii group has small apical openings similar to $D$. crux darwinii, but its members are distinguished by basal pikes and relatively smaller apical areas.

The stratigraphic occurrence, size, and proportions of Distephanus crux darwinii all suggest that it developed from Oligocene Dictyocha deflandrei. If this is true, this poses a problem in terms of natural classification because it suggests that the genus Distephanus, if defined simply by the criterion of an apical ring, is polyphyletic. Future con- sideration of accessory structures such as basal pikes (Dumitrica, 1973; Poelchau, 1974) septate spines (Dumitrica, 1973), and surface textures (Jerkovic:, 1969; Mandra and Mandra, 1972; McPherson and Ling, 1973), should help develop a more natural classification for the study of silicoflagellate phylogeny.

Occurrence: Distephanus crux darwinii is common to abundant in the upper Oligocene in Hole 328B. It occurs reworked at Site 329.

Size: Internal diameter 14-20 $\mu \mathrm{m}$; holotype $19 \mu \mathrm{m}$.

Holotype: USNM 221631 (Plate 7, Figures 6, 7).

Paratypes: USNM 2216.32 to 221637.

Type locality: Falkland outer basin, South Atlantic Ocean, Sample $328 \mathrm{~B}-3-1,109-110 \mathrm{~cm}(28 \mathrm{~m})$.

\section{Distephanus crux hannai Bukry}

Distephanus crux hannai Bukry, 1975d, p. 855, pl. 4, fig. 4-6.

\section{Distephanus polyactis (Ehrenberg)}

Dictyocha polyactis Ehrenberg, 1839, p. 129.

Distephamus polyactis Ehrenberg, Perch-Nielsen, 1975, p. 688, pl. 7, fig. 12; pl. 11, fig. 11 .

\section{Distephanus raupii n. sp.}

(Plate 7, Figures 14, 15)

Distephanus speculum pentagonus (Lemmermann), Bukry, 1975d (in part), p. 867 , pl. 4 , fig. 9,10 (not 11).

Description: Distephanus raupii has a small pentagonal basal ring and short to moderate spines. The corners of the basal ring are rounded or angular; there are no basal pikes on the ring. The apical structure is broad, occupying $30 \%$ to $50 \%$ of the interring area, however, the rounded apical opening is generally small. The strut-basal ring junctures are offset from the midpoints of the sides of the basal ring.

Remarks: Distephanus raupii is distinguished from Distephanus speculum pentagonus by the absence of basal pikes, smaller more rounded apical opening, and generally smaller overall size. Because of its small, compact form, the absence of basal pikes, and its stratigraphic occurrence, $D$. raupii most likely evolved from the Dictyocha deflandrei and Distephamus crux darwinii lineage.

Occurrence: Distephanus raupii occurs in upper Oligocene and lower Miocene silicoflagellate assemblages from the Pacific and Atlantic oceans at Sites 278 and 328.

Size: Basal ring inner diameter $15-25 \mu \mathrm{m}$.

Holotype: USNM 221638 (Plate 7, Figures 14, 15)

Type locality: Falkland outer basin, South Atlantic Ocean, Sample $328 \mathrm{~B}-3-5,100-102 \mathrm{~cm}(34 \mathrm{~m})$.

\section{Distephanus schauinslandii stradneri Jerković}

Dictyocha schauinslandii stradneri Jerković, 1965, p. 3, pl. 2, fig. 2. Distephanus crux Ehrenberg, Dumitrica, 1973 (in part), p. 850, pl. 6, fig. 11.

Distephanus schauinslandii stradneri (Jerković), Bukry, 1975, p. 866, pl. 4 , fig. 7.

Remarks: Large cruxoid specimens with small apical openings and nearly equant major and minor axis are assigned to this taxon.

\section{Distephanus speculum hemisphaericus (Ehrenberg)}

Dictyocha hemisphaerica Ehrenberg 1844b, p. 258, 266.

Cannopilus hemisphaericus (Ehrenberg), Locker, 1974, p. 639, pl. 4, fig. 1, 4, 5, 7, 8 .

Distephanus speculum hemisphaericus (Ehrenberg) Bukry 1975d, p. 855 , pl. 4 , fig. 8 .

Destephanus speculum minutus (Bachmann) (Plate 8, Figures 1-3)

Dictyocha speculum f. minuta Bachmann in Ichikawa et al., 1967, p. 161 , pl. 7, fig. 12-15.

Distephanus minutus (Bachmann) Bukry and Foster, 1973, p. 828, pl. 4, fig. 10, 11 .

Remarks: Specimens from Leg 36 have exceptionally wide apical rings, nearly as wide as the basal ring. Although six-spined forms predominate, eight-spined forms having distinct basal pikes are common in Cores 4 to 6 at Site 329 .

\section{Distephanus speculum pentagonus Lemmermann}

Distephanus speculum var, pentagonus Lemmermann, 1901, p. 264, pl. 11 , fig. 19. 
Distephanus quinquangellus Bukry and Foster nomen novum, 1973, p. 838 , pl. 5 , fig. 4 .

Remarks: This taxon is perplexing because of its form, distribution, and potential polyphyletic origins (see Distephanus boliviensis boliviensis). In many assemblages it is obviously related to the more abundant Distephanus speculum speculum specimens by size, proportions, and ornamentation. Such forms cannot be considered as distinct species in a natural scheme of classification. But other assemblages have abundant " $D$. speculum pentagonus" whose form is not matched by any associated specimens of $D$. speculum speculum, for example, the smallcentered forms at Site 278, Core 28 (Bukry, 1975d). By their size, proportion, and absence of basal pikes the late Oligocene or early Miocene populations of pentagonal specimens of Distephanus (Sites 328B and 278) show closer affinity to the Distephanus crux darwinii group than to the type of $D$. speculum pentagonus which has distinct basal pikes and a large polygonal apical ring. These pentagonal specimens are distinguished herein as Distephanus raupii.

\section{Distephanus speculum pseudofibula Schulz}

Distephanus speculum f. pseudofibula Schulz, 1928, p. 262, fig. 51a, b.

Remarks: The apical bar of Distephanus speculum pseudofibula seems to suggest assignment to the genus Dictyocha, as does its paleotemperature significance at DSDP 173 (Ingle, 1973). The hexagonal base, however, suggests a relation to Distephanus speculum. Curiously, it occurs as part of a double skeleton with $D$. speculum varians (symmetric) at Site 329 (Plate 8 , Figures 8, 9). Therefore, the distinction of $D$. speculum varians from $D$. speculum pseudofibula seems artificial. The lack of an apical ring in each of the paired skeletons does not support the relation of these two taxa to $D$. speculum. The regular hexagonal basal ring, however, is believed to be a character trait better ascribed to Distephanus than to Dictyocha. When more double skeletons are studied, it may be found to be appropriate to elevate $D$. speculum pseudofibula to species rank within Distephanus.

Distephanus speculum quintus (Bukry and Foster)

Cannopilus quintus Bukry and Foster, 1973, p. 826, pl. 1, fig. 8, 9; pl. 2, fig. 1.

Distephanus speculum quintus (Bukry and Foster) Bukry, 1975d, p. 855 .

\section{Distephanus speculum speculum (Ehrenberg)}

Dictyocha speculum Ehrenberg, 1839, p. 150; Ehrenberg, 1854, pl. 18, fig. 57 ; pl. 19 , fig. 41 ; pl. 21 , fig. 44 ; pl. 22 , fig. 47 .

Remarks: Specimens with many different proportions are included in Distephanus speculum speculum. Radially and bilaterally symmetric forms are not separated for this report, nor are short- and long-spined forms. Several abnormal specimens of D. speculum s. ampl. are illustrated (Plate 8, Figures 4, 6).

\section{Distephanus speculum varians Gran and Braarud} (Plate 8, Figures 7-10)

Distephanus speculum f. varians Gran and Braarud, 1935, p. 390, fig. $68 \mathrm{~A}, \mathrm{~B}$.

Distephanus speculum varians (Gran and Braarud), Bukry 1975d, p. 868 , pl. 5 , fig. 3 .

Remarks: Two morphotypes were orginally illustrated for this subspecies. Because the work of Ciesielski and Weaver (1973) suggested some difference in the ranges of the symmetric and asymmetric forms of Distephanus speculum varians, they were tabulated separately at several Leg 36 sites. No significant difference in range was noted. Ling (1972) considered the pseudofibula-varians complex to represent a single phenotype suite (see remarks for Distephanus speculum pseudofibula, this chapter). Clearcut differences in skeletal form do not necessarily reflect different taxa (see Plate 8 , Figures 8,9 ).

Some specimens of Dictyocha fibula hexagona Marshall (see Loeblich et al., 1968) mimic the form of Distephanus speculum varians, but their struts are peculiarly widened.

Distephanus speculum triommata (Ehrenberg) n. comb.

Dictyocha triommata Ehrenberg, 1845, p. 56, 76.

Dictyocha triommata Ehrenberg, Locker, 1974, p. 639, 643, pl. 4, fig. 5
Genus LYRAMULA Hanna, 1928

Lyramula furcula Hanna

Lyramula furcula Hanna, 1928, p. 262, pl. 41, fig. 4 , 5.

Genus MESOCENA Ehrenberg, 1843

Remarks: For this report all silicoflagellates constructed as a single ring are assigned to genus Mesocena.

\section{Mesocena apiculata (Schulz)}

Mesocena oamaruensis apiculata Schulz, 1928, p. 240, fig. 11. Mesocena apiculata (Schulz), Bukry, 1975d, p. 856, pl. 5, fig. 6-9.

\section{Mesocena circulus (Ehrenberg)}

Mesocena circulus (Ehrenberg) Ehrenberg, 1844a, p. 65.

Mesocena circulus Ehrenberg, Ling, 1972, p. 175, pl. 28, fig. 5, 6. Mesocena circulus (Ehrenberg), Bukry, 1975d, p. 868, pl. 6, fig. 1, 2.

Remarks: The several forms of Mesocena circulus are tabulated together. Polygonal, coarse-spined forms (see Ling, 1972) dominate at Site 329.

\section{Mesocena diodon Ehrenberg}

Mesocena diodon Ehrenberg, 1844a, p. 71, 84 .

Mesocena diodon Ehrenberg, Bukry, 1973, p. 830, pl. 3, fig. 4, 5.

\section{Mesocena elliptica (Ehrenberg)}

Mesocena elliptica (Ehrenberg) Ehrenberg, 1844a, p. 71, 84.

Mesocena elliptica (Ehrenberg) Bukry and Foster, 1973, p. 828, pl. 6, fig. $2-4$.

Mesocena oamaruensis quadrangula Schulz

Mesocena oamaruensis quadrangula Schulz, 1928, p. 240, fig. 12, 13.

Mesocena pappii Bachmann

Mesocena pappii Bachmann, 1962, p. 380, pl. 1, fig. 1-9.

\section{Mesocena pentagona Haeckel}

Mesocena pentagona Haeckel, 1887, p. 1556; Lemmermann, 1901, pl. 10 , fig. 8 .

\section{Mesocena triangula (Ehrenberg)}

Mesocena triangula (Ehrenberg) Ehrenberg, 1844a, p. 65, 71. Mesocena triangula (Ehrenberg), Bukry and Foster, 1973, p. 829, pl. 6, fig. $9,10$.

\section{Mesocena sp.}

Mesocena oamaruensis Schulz, Perch-Nielsen, 1975 (in part), p. 688, pl. 10, fig. 20.

\section{Genus NAVICULOPSIS Frenguelli, 1940}

Remarks: The species concepts for Naviculopsis are the same as those used for DSDP Leg 29 (Bukry, 1975d). Two additional species recognized for DSDP Leg 36 are based on Perch-Nielsen (in press).

\section{Naviculopsis aspera (Schulz) \\ (Plate 8, Figures 11, 12)}

Dictyocha navicula var. aspera Schulz, 1928, p. 246, fig. 20a, b.

Naviculopsis aspera (Schulz) Perch-Nielsen, in press, p. , pl. 1, fig. 8, 9; pl. 3, fig. 7, 10, 11.

Remarks: The narrow apical band appears to be continuous with the body ring and to have a rim along its margins in light microscopy. Because the surface texture is indistinct in light microscopy, the rim along the apical band and body ring is used to distinguish the compared specimens in Hole 327A from Naviculopsis constricta.

\section{Naviculopsis biapiculata (Lemmermann)}

?Dictyocha navicula biapiculata Lemmerman, 1901, p. 258, pl. 10, fig. $14,15$.

Remarks: The specimens in Hole 328B match those from DSDP Legs 28 and 29 in form and size. The apical bar is distinctly arched. A few compared specimens have a short spire on the apical bar. These 
specimens mimic Naviculopsis trispinosa but are distinguished by the small size of the spire. The apical spine of $N$. trispinosa is typically the same size as the spines on the basal ring.

\section{Naviculopsis constricta (Schulz)}

(Plate 9, Figures 1, 2)

Dictyocha navicula biapiculata constricta Schulz, 1928, p. 246, fig. 21. Dictyocha navicula minor Schulz, 1928, p. 246, fig. 22.

Naviculopsis constricta (Schulz) Frenguelli, 1940, p. 61, fig. 11a, b. Naviculopsis minor (Schulz) Frenguelli, 1940, p. 61, fig. 11 i.

Remarks: Specimens having short and elongate basal rings and long and short apical spines occur through the Paleocene to Oligocene range of this species. The elongate form is typically less abundant. Because the two forms are considered conspecific the name Naviculopsis constricta has figure priority.

\section{Naviculopsis danica Perch-Nielsen} (Plate 9, Figure 3)

Naviculopsis danica Perch-Nielsen, in press, p. , pl. 1, fig. 5, 6; pl. 2 , fig. 5 .

Remarks: The single specimen from the Falkland Plateau shows the same proportions as the type Danish suite (Perch-Nielsen, in press).

\section{Naviculopsis foliacea Deflandre}

Naviculopsis foliacea Deflandre 1950, p. 203, fig. 235-239.

\section{Naviculopsis navicula (Ehrenberg)}

Dictyocha navicula Ehrenberg, 1839, p. 129.

Naviculopsis navicula (Ehrenberg), Ling, 1972, p. 186, pl. 31, fig. 1. Naviculopsts navicula (Ehrenberg), Locker, 1974 (in part), p. 635, pl. 2, fig. 1 .

Remarks: The internal breadth of the two ends of this boat-shaped species is approximately one half the breadth in the region of the apical bar. Characteristically, Naviculopsis navicula has no spines, but rare specimens having one or two spines occur. The tubular basal ring is not broadened at the ends.

\section{Naviculopsis ponticula (Ehrenberg) n. comb.}

Dictyocha ponticulus Ehrenberg, 1844b, p. 258, 267.

Naviculopsis navicula (Ehrenberg), Martini, 1972, p. 120, text-fig. 2. Naviculopsis quadrata (Ehrenberg), Bukry and Foster, 1973, p. 306, fig. 2e.

Naviculopsis navicula (Ehrenberg), Locker, 1974 (in part: lectotype illustration of Dictyocha ponticulus Ehrenberg), p. 635, pl. 2, fig. 2, (not fig. 1).

Remarks: According to the illustration of Locker (1974), the lectotype of Dictyocha ponticulus Ehrenberg shows the ends of the basal ring distinctly broader than the other tubular portions of the ring. This is an easily determined morphologic feature. Specimens showing this feature should be distinguished from Naviculopsis navicula sensu stricto (Locker, 1974, pl. 2, fig. 1) until the stratigraphic and ecologic significance of this structural difference is determined.

\section{Naviculopsis quadrata (Ehrenberg)}

Dictyocha quadrata Ehrenberg, 1844b, p. 258, 267; fide Loeblich et al., 1968 , p. 105 , pl. 19, fig. 12.

Dictyocha navicula rectangulare Schulz, 1928, p. 243, fig. 17a, b.

\section{Naviculopsis trispinosa (Schulz)}

Dictyocha navicula trispinosa Schulz, 1928, p. 246, fig. 23a, b. Naviculopsis trispinosa (Schulz), Perch-Nielsen, 1975, p. 689, pl. 12, fig. $1-4$; pl. 13, fig. 1-10.

\section{Genus VALLACERTA Hanna, 1928}

Vallacerta tumidula Glezer

Vallacerta tumidula Glezer, 1959, p. 104, 107, fig. 4, 5 .

Remarks: A single pentagonal specimen was observed in the upper Paleocene of Hole 327A.

\section{ACKNOWLEDGMENT}

I thank Herman Adler, Campbell, California; J.A. Barron and G.W. Moore, U.S. Geological Survey, Menlo Park, California; and Katharina Perch-Nielsen, Geologisches Insti- tute ETH, Zurich, Switzerland, for constructive insights and discussions on various aspects of this study. A specially mounted slide of Stictodiscus gelidus Mann from Baja California was provided by Herman Adler.

\section{REFERENCES}

Bachmann, A., 1962. Eine neue Mesocena-Art (Silicoflagellidae) aus dem kalifornischen Eozän: Osterreichische Geol. Bundesanst. Verh., Jb. 1962, p. 378383.

Bachmann, A. and Keck, A., 1969. Die Oberflächenstruktur der Silicoflagellaten: Mikrokosmos, v. 7, p. 204-207.

Bukry, D., 1973. Coccolith and silicoflagellate stratigraphy, Deep Sea Drilling Project Leg 18, eastern North Pacific. In Kulm, L.D., von Huene, R., et al., Initial Reports of the Deep Sea Drilling Project, Volume 18: Washington (U.S. Government Printing Office), p. 817-831.

1974. Stratigraphic value of silicoflagellates in nontropical regions: Geol. Soc. Am. Bull., v. 85, p. 1905-1906. 1975a. Biostratigraphy of Cenozoic marine sediment by calcareous nannofossils: 3rd Plankt. Conf. Proc., Kiel.

1975b. Coccolith and silicoflagellate stratigraphy near Antarctica, Deep Sea Drilling Project Leg 28. In Hayes, D., Frakes, L.A., et al., Initial Reports of the Deep Sea Drilling Project, Volume 28: Washington (U.S. Government Printing Office), p. 709-723.

1975c. Coccolith and silicoflagellate stratigraphy, northwestern Pacific Ocean, Deep Sea Drilling Project Leg 32. In Larson, R.L., Moberly, R., et al., Initial Reports of the Deep Sea Drilling Project, Volume 32: Washington (U.S. Government Printing Office), p. 677-701.

1975d. Silicoflagellate and coccolith stratigraphy, Deep Sea Drilling Project Leg 29. In Kennett, J.P., Houtz, R.E., et al., Initial Reports of the Deep Sea Drilling Project, Volume 29: Washington (U.S. Government Printing Office), p. 715-735.

, 1976. Silicoflagellate and coccolith stratigraphy, southeastern Pacific Ocean, Deep Sea Drilling Project Leg 34. In Hart, S.R., Yeats, R.S., et al., Initial Reports of the Deep Sea Drilling Project, Volume 34: Washington (U.S. Government Printing Office).

Bukry, D., and Foster, J.H., 1973. Silicoflagellate and diatom stratigraphy, Leg 16, Deep Sea Drilling Project. In van Andel, T.H., Heath, G.R., et al., Initial Reports of the Deep Sea Drilling Project, Volume 16: Washington (U.S. Government Printing Office), p. 815-871.

1974. Silicoflagellate zonation of Upper Cretaceous to lower Miocene deep-sea sediment: U.S. Geol. Surv. J. Res., v. 2, p. 303-310.

Ciesielski, P.F., 1975. Biostratigraphy and paleoecology of Neogene and Oligocene silicoflagellates from cores recovered during Antarctic Leg 28, Deep Sea Drilling Project. In Hayes, D., Frakes, L.A., et al., Initial Reports of the Deep Sea Drilling Project, Volume 28: Washington (U.S. Government Printing Office), p. 625-691.

Ciesielski, P.F. and Weaver, F.M., 1973. Southern Ocean Pliocene paleotemperatures based on silicoflagellates from deep-sea cores: U.S. Antarctic J., v. 8, p. 295-297.

Deflandre, G., 1941. Les notions de genre et de grade chez les Silicoflagellidées et la phylogenèse des mutants naviculaires: C.R. Acad. Sci., v. 212, p. 100-102.

1950. Contribution a l'étude des silicoflagellidés actuels et fossiles: Microscopie, v. 2, p. 72-108, 117-142, and 191-210.

Dumitrica, P., 1973. Paleocene, late Oligocene and post-Oligocene silicoflagellates in southwestern Pacific sediments cored on Deep Sea Drilling Project, DSDP Leg 21. In Burns, R.E., Andrews, J.E., et al., Initial Reports of the Deep Sea Drilling Project, Volume 21: Washington (U.S. Government Printing Office), p. 837-883. 
Ehrenberg, C.G., 1938. Uber die Bildung der Kreidefelsen und des Kreidemergels durch unsichtbare Organismen: K. Preuss. Akad. Wiss. Berlin Ber., Jahrg. 1838, p. 59-148.

1840. Uber noch jetzt zahlreich lebende Thierarten der Kreidebildung und den Organismus der Polythalamien: K. Preuss. Akad. Wiss. Berlin Ber., Jahrg. 1839, p. 81-174. 1844a. Mittheilung uber zwei neue Lager von Gebirgsmassen aus Infusorien als Meeres-Absatz in NordAmerika und eine Vergleichung derselben mit den organischen Kreide-Gebilden in Europa und Afrika: K. Preuss. Akad. Wiss. Berlin Ber., Jahrg. 1844, p. 57-97. $1844 b$. Untersuchungen über die kleinsten Lebensformen im Quellenlande des Euphrats und Araxes, so wie über eine an neuen Formen sehr reiche marine Tripelbildung von den Bermuda-Inseln vor.: K. Preuss. Akad. Wiss. Berlin Ber., Jahrg. 1844, p. 253-275.

1845. Neue Untersuchungen über das kleinste Leben als geologisches Moment.: K. Preuss. Akad. Wiss. Berlin Ber., Jahrg. 1845, p. 53-87. 374. 1854. Mikrogeologie: Leipzig (Leopold Voss), p. 1-

Frenguelli, J., 1940. Consideraciones sobre los sílicoflagelados fósiles: Mus. La Plata Rev., Paleontol., v. 2, p. 37-112.

1951. Silicoflagelados del Trípoli de Mejillones (Chile): Physis [Buenos Aires], v. 20, p. 272-284.

Glezer, Z.I., 1959. Nekotorye novye dannye o semeistve Vallacertaceae Deflandre (Silicoflagellatae) [Some new data on the Family Vallacertaceae Deflandre (Silicoflagellatae)] Vses. Nauchno-Issled. Geol. Inst. Inform. Sbornik, Strat. i Paleont., no. 10 , p. 103-113.

1960. Paleogenovye kremnevye zhgutikovye vodorosli (Silicoflagellatae) Zapadnoy Sibiri [Paleogene silicoflagellates of western Siberia]: Vses. Nauchno-Issled. Geol. Inst. Inform. Sbornik, Strat. i Paleont., no. 35, p. $127-136$.

1964. Novye kremnevye zhgutikovye vodorosli Paleogena SSSR [New silicoflagellates from the Paleogene of the USSR]: Akad. Nauk SSSR, Novosti sistematiki nizshikh rasteniy, otdel. ottisk, p. 46-58.

, 1966. Silicoflagellatophyceae, In Gollerbakh, M.M.

(Ed.), Cryptogamic plants of the U.S.S.R.: Akad. Nauk SSSR, V.A. Komarova Bot. Inst. (Translated from Russian by Israel Program for Scientific Translations Ltd., Jerusalem, 1970), v. 7, p. 1-363.

Gran, H.H. and Braarud, T., 1935. A quantitative study of the phytoplankton in the Bay of Fundy and the Gulf of Maine (including observations on hydrography, chemistry and turbidity): J. Biol. Board Canada, v. 1, p. 280-467.

Haeckel, E.H.P.A., 1887. Cannorrhaphida: Challenger Rept., v. 18 , p. $1546-1569$.

Hajós, M., 1975. Late Cretaceous Archaeomonadaceae, Diatomaceae, and Silicoflagellatae from the South Pacific Ocean, Deep Sea Drilling Project Leg 29, Site 275. In Kennett, J.P., Houtz, R.E., et al., Initial Reports of the Deep Sea Drilling Project, Volume 29: Washington (U.S. Government Printing Office), p. 913-1009.

Hanna, G.D., 1928. Silicoflagellata from the Cretaceous of California: J. Paleontol., v. 1, p. 259-263.

, 1929. Fossil diatoms dredged from Bering Sea: San Diego Soc. Nat. History Trans., v. 5, p. 287-296. 1930. A new genus of Silicoflagellata from the Miocene of Lower California: J. Paleontol., v. 4, p. 415416.

Ichikawa, W., Shimizu, I., and Bachmann, A., 1967. Fossil silicoflagellates and their associated uncertain forms in Iida Diatomite, Noto Peninsula, Central Japan: Kanazawa Univ. Sci. Rept., v. 12, p. 143-172.

Ingle, J.C., Jr., 1973. Summary comments on Neogene biostratigraphy, physical stratigraphy, and paleooceanography in the marginal northeastern Pacific Ocean:
In Kulm, L.D., von Huene, R., et al., Initial Reports of the Deep Sea Drilling Project, Volume 18: Washington (U.S. Government Printing Office), p. 949-960.

Jerković, L., 1965. Sur quelques silicoflagellidés de Yougoslavie: Lab. Micropaleont., Inst. Paleont. Museum Paris, p. 1-8.

1969. Les nouvelles recherches de la superficie du squelette des silicoflagellidés: Univ. Sarajevu Biol. Inst. Godisnjaka, v. 22, p. 129-176.

Lemmermann, E., 1901. Silicoflagellatae: Deutsche. Bot. Gesell. Ber., v. 19, p. 247-271.

Ling, H.Y., 1972. Upper Cretaceous and Cenozoic silicoflagellates and ebridians: Am. Paleontol. Bull., v. 62, p. 135-229.

1973. Silicoflagellates and ebridians from Leg 19. In Creager, J.S., Scholl, D.W., et al., Initial Reports of the Deep Sea Drilling Project, Volume 19: Washington (U.S. Government Printing Office), p. 751-775.

1975. Silicoflagellates and ebridians from Leg 31. In Ingle, J.C., Karig, D.E., et al., Initial Reports of the Deep Sea Drilling Project, Volume 31: Washington (U.S. Government Printing Office), p. 763-777.

Locker, S., 1974. Revision der Silicoflagellaten aus der Mikrogeologischen Sammlung von C.G. Ehrenberg: Eclog. Geol. Helv., v. 67, p. 631-646.

Loeblich, A.R., 3d, Loeblich L.A., Tappan, H., and Loeblich, A.R., Jr., 1968. Annotated index of fossil and recent silicoflagellates and ebridians with descriptions and illustrations of validly proposed taxa: Geol. Soc. Am. Mem. 106, p. 1-319.

Mandra, Y.T. and Mandra, H., 1972. Paleoecology and taxonomy of silicoflagellates from an upper Miocene diatomite near San Felipe, Baja California, Mexico: California Acad. Sci. Occasional Paper 99, p. 1-35.

Martini, E., 1972. Silicoflagellate zones in the late Oligocene and early Miocene of Europe: Senckenb. Lethaea, v. 53, p. 119-122.

McPherson, L.M. and Ling, H.Y., 1973. Surface microstructure of selected silicoflagellates: Micropaleontology, v. 19, p. $475-480$.

Muhina, V.V., 1974. Paleocenovye diatomovye ily v vostochnoj chasti Indijskogo Okeana (Paleocene diatomaceous ooze in the eastern part of the Indian Ocean): Okeanologiya, v. 14, p. 852-858.

Perch-Nielsen, K., 1975. Late Cretaceous to Pleistocene silicoflagellates from the southern southwest Pacific, DSDP Leg 29. In Kennett, J.P., Houtz, R.E., et al., Initial Reports of the Deep Sea Drilling Project, Volume 29: Washington (U.S. Government Printing Office), p. 677-721.

, in press. New silicoflagellates and a silicoflagellate zonation in north European Eocene diatomites: Geol. Soc. Denmark Bull.

Poelchau, H.S., 1974. Holocene silicoflagellates of the North Pacific: Their distribution and use for paleotemperature determination: Ph.D. dissertation, University of California, San Diego, p. 1-165.

Schulz, P., 1928. Beiträge zur Kenntnis fossiler und rezenter Silicoflagellaten: Bot. Archiv. v. 21, p. 225-292.

Stradner, H., 1961. Uber fossile Silicoflagelliden und die Möglichkeit ihrer Verwendung in der Erdölstratigraphie: Erdöl Kohle, v. 14, p. 87-92.

Uchio, T., 1974. Tertiary nannoplankton stratigraphy of Sado Island, Niigata Prefecture, and a proposal of the Braarudosphaera bigelowi-Coccolithus pelagicus Zone for the Pliocene of Japanese oil fields of Japan Sea side: Japan Geol. Surv. Rept., no. 250-1, p. 235-254.

Van Valkenburg, S.D. and Norris, R.E., 1970. The growth and morphology of the silicoflagellate Dictyocha fibula Ehrenberg in culture: J. Phycol., v. 6, p. 48-54. 



\section{PLATE 1}

Silicoflagellates from DSDP Leg 36

Figures 1, 3-9, 12; scale bar equals $10 \mu \mathrm{m}$.

Figures 2, 10, 11; scale bar equals $20 \mu \mathrm{m}$.

Figures 1-4 Corbisema disymmetrica angulata n. subsp.

1. USNM 221575, Sample 327A-5-2, 100-102 cm $(45 \mathrm{~m})$.

2. USNM 221576, Sample 327A-5-2, 100-102 cm (45 m).

3. USNM 221577, Sample 327A-5-4, 100-102 cm $(48 \mathrm{~m})$.

4. Holotype, USNM 221574, Sample 327A-5-4, $100-102 \mathrm{~cm}(48 \mathrm{~m})$.

Figures 5-9 Corbisema disymmetrica communis n. subsp.

5. USNM 221579, Sample 327A-8-3, $43-44 \mathrm{~cm}$ (74 m).

6. USNM 221580, Sample 327A-8-3, $43-44 \mathrm{~cm}$ (74 m).

7. USNM 221581, Sample 327 A-8-1, $130-132 \mathrm{~cm}$ (72 m).

8. Holotype, USNM 221578, Sample 327A-6-6, $130-132 \mathrm{~cm}(61 \mathrm{~m})$.

9. USNM 221582, Sample 327A-5-1, 60-62 cm $(43 \mathrm{~m})$.

Figures 10-12 Corbisema disymmetrica disymmetrica (Dumitrica) n. comb.

10. Sample $327 \mathrm{~A}-6-3,100-102 \mathrm{~cm}(56 \mathrm{~m})$.

11. Sample $327 \mathrm{~A}-8-1,130-132 \mathrm{~cm}(72 \mathrm{~m})$.

12. Sample $327 \mathrm{~A}-5-2,100-102 \mathrm{~cm}(45 \mathrm{~m})$, fragment. 
PLATE 1
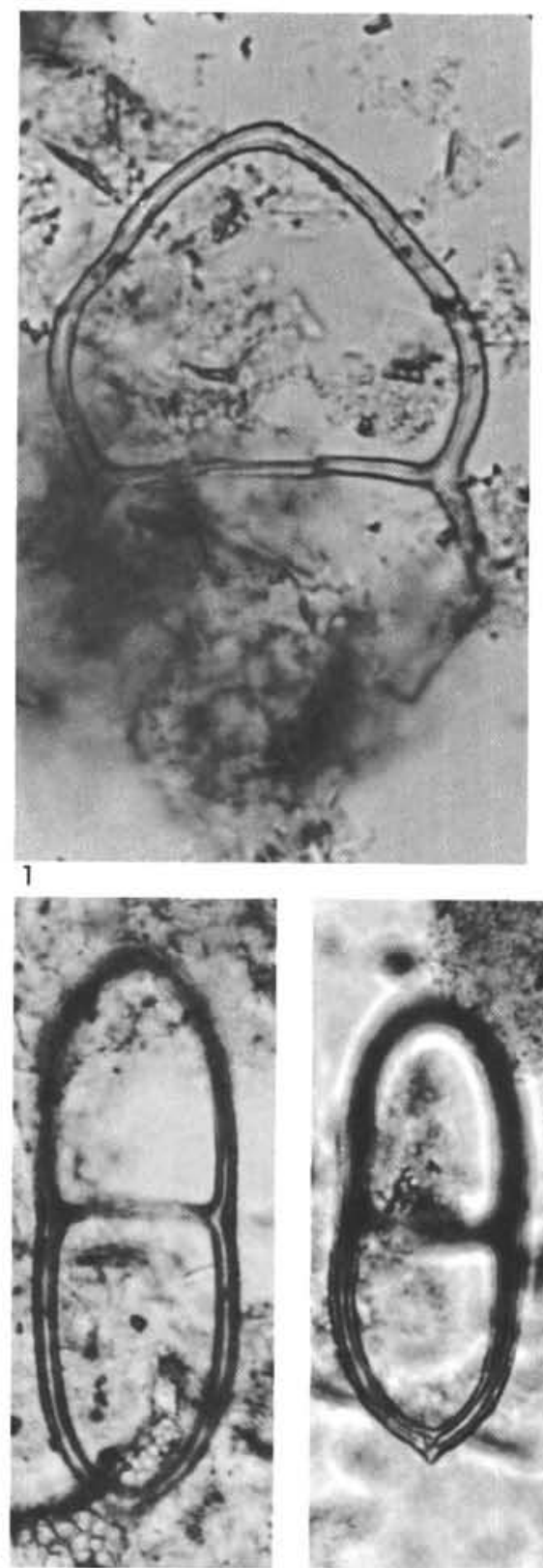

5

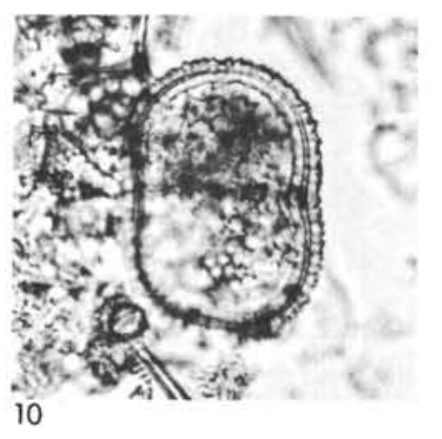

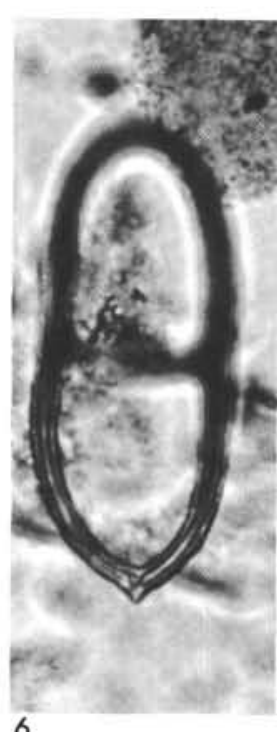

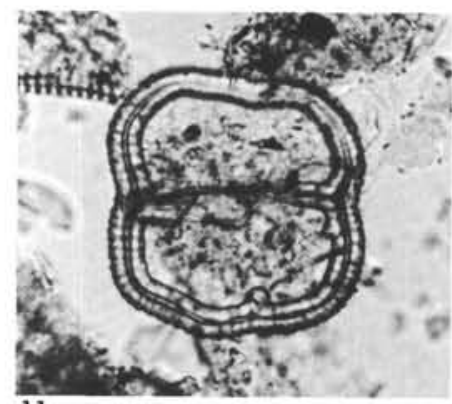

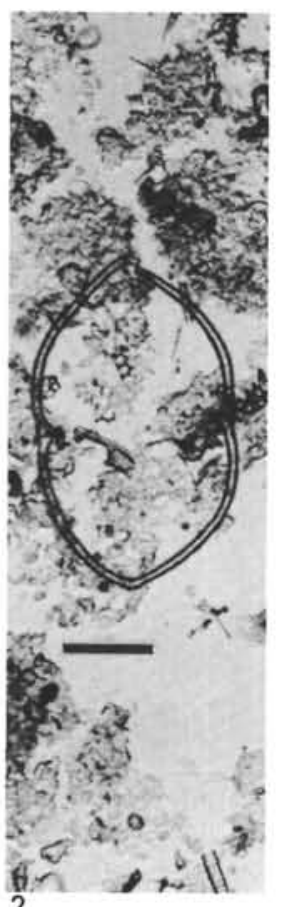
2
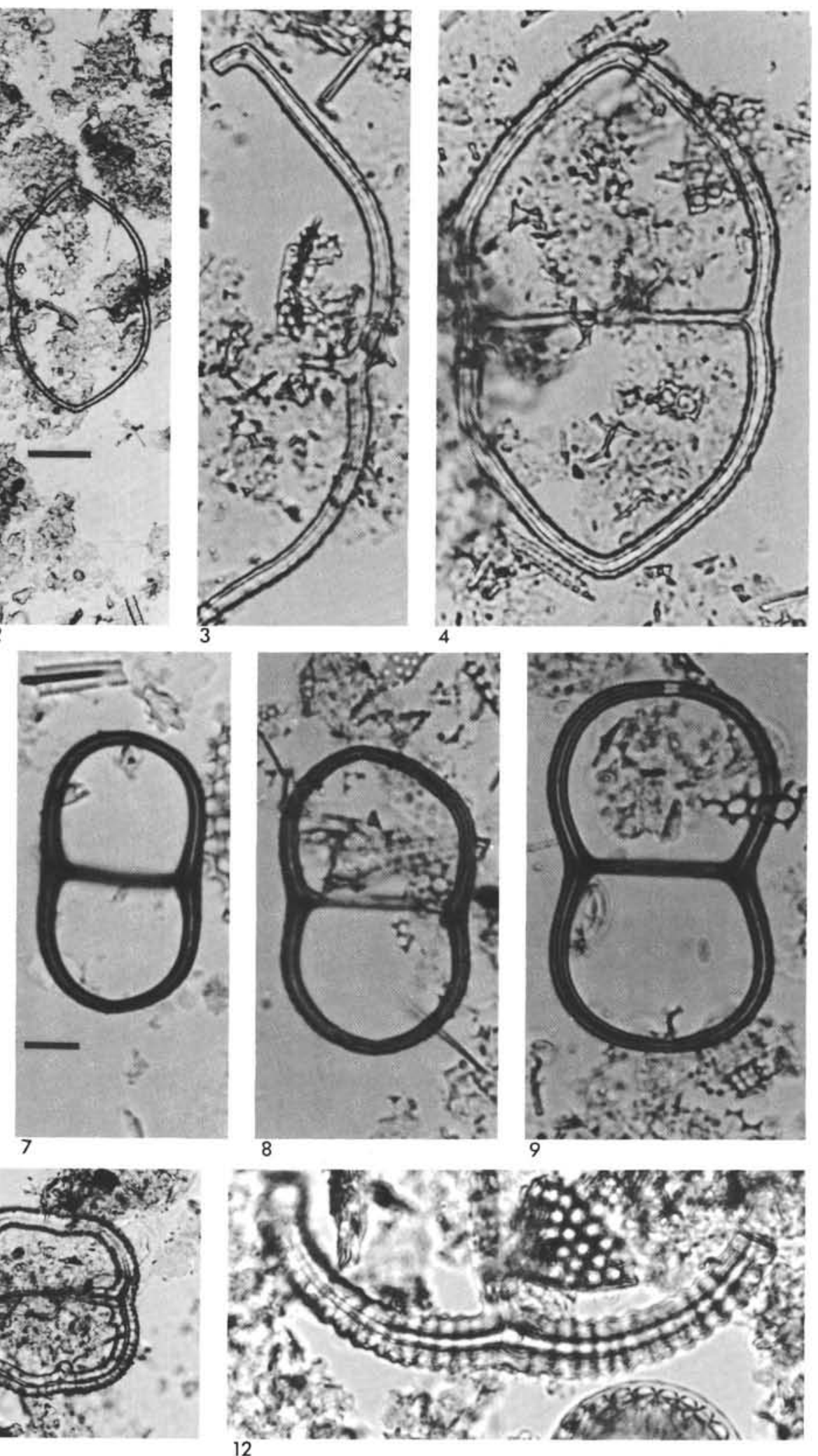
PLATE 2

Silicoflagellates from DSDP Leg 36.

Scale bar equals $10 \mu \mathrm{m}$ for all figures.

Figures 1-15 Corbisema falklandensis $\mathrm{n}$. sp.

1, 2. USNM 221584, Sample 327A-5-4, 100-102 $\mathrm{cm}(48 \mathrm{~m})$, apical and basal focuses.

3, 4. USNM 221585, Sample 327A-5-4, 100-102 $\mathrm{cm}(48 \mathrm{~m})$, apical and basal focuses.

5. (USNM 221586, Sample 327A-5-2, 100-102 cm $(45 \mathrm{~m})$, apical focus.

6, 7. USNM 221587, Sample 327A-6-1, 9-10 cm (52 $\mathrm{m})$, apical and basal focuses.

8, 9. Holotype, USNM 221583, Sample 327A-6-1, $9-10 \mathrm{~cm}(52 \mathrm{~m})$, apical and basal focuses.

10. USNM 221588, Sample 327A-6-3, 100-102 cm (56 m), basal focus.

11. USNM 221589, Sample 327A-7-2, 3-4 cm (62 $\mathrm{m})$, apical focus.

12. USNM 221590 , Sample $327 \mathrm{~A}-6-1,9-10 \mathrm{~cm}$ (52 $\mathrm{m})$, side view.

13. USNM 221591, Sample 327A-5-5, 100-102 cm (45 m), side view.

14, 15. USNM 221592, Sample 327A-6-3, 100-102 $\mathrm{cm}(54 \mathrm{~m})$, apical and basal focuses. 
PLATE 2
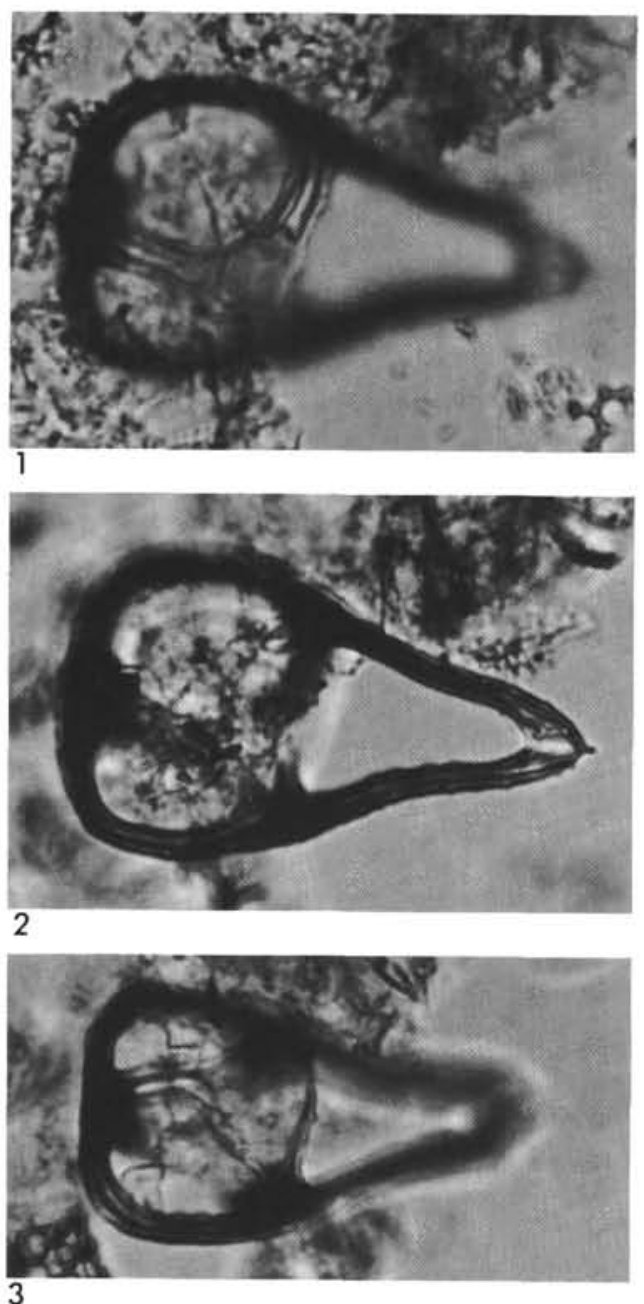

3

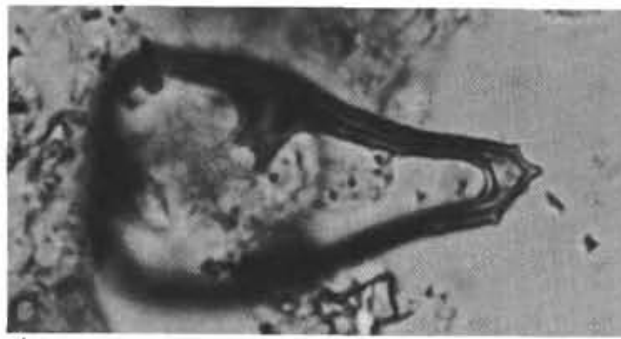

4

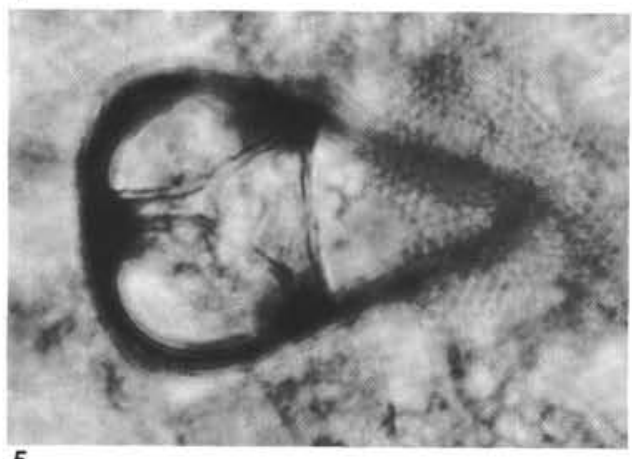

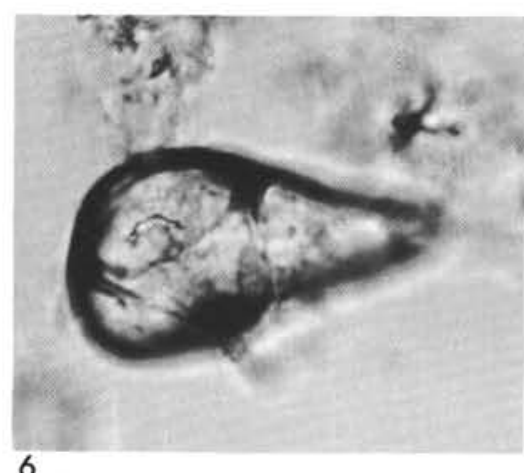
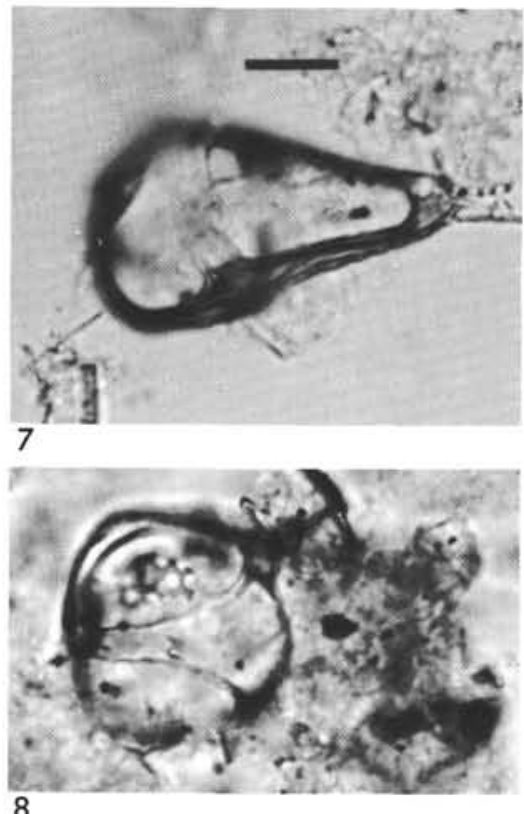

8
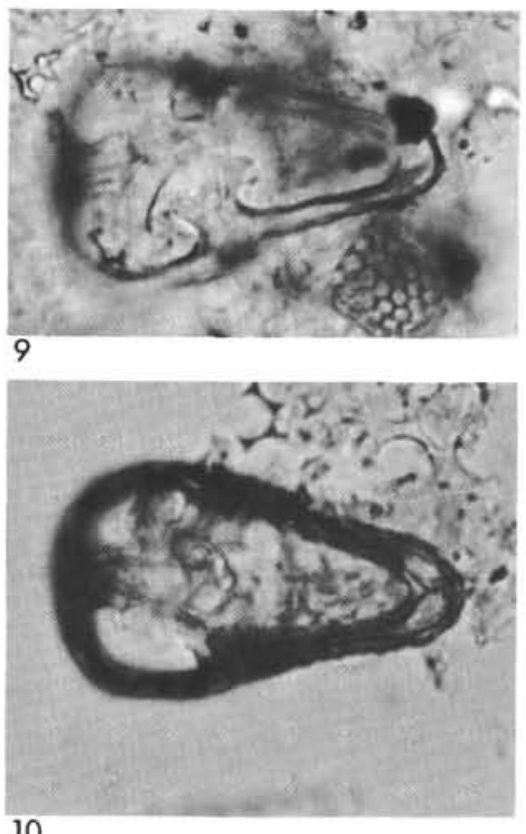

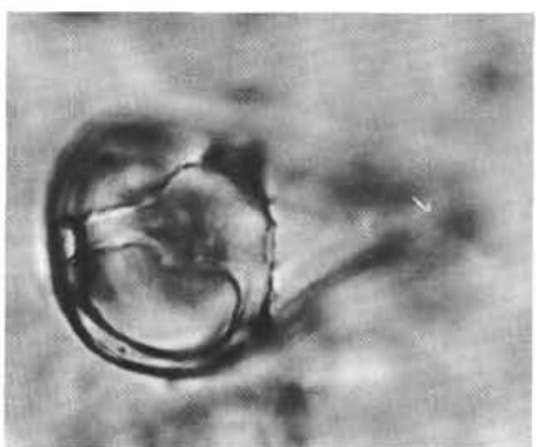

11

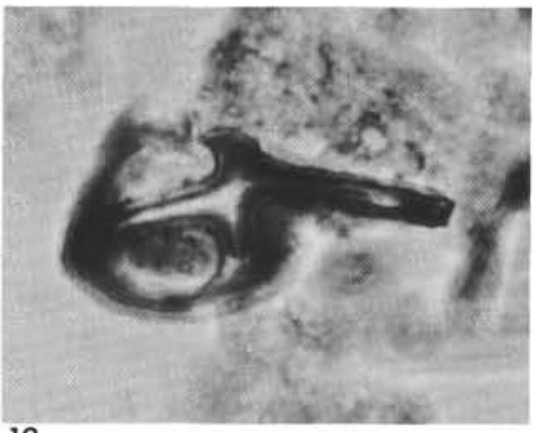

12

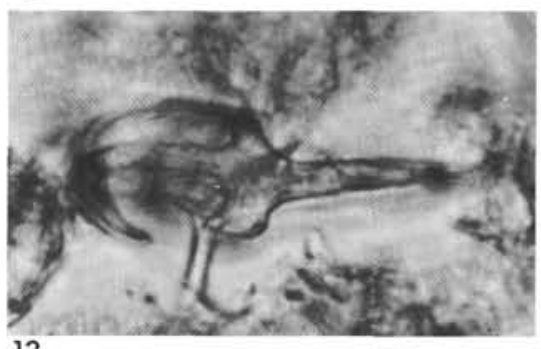

13

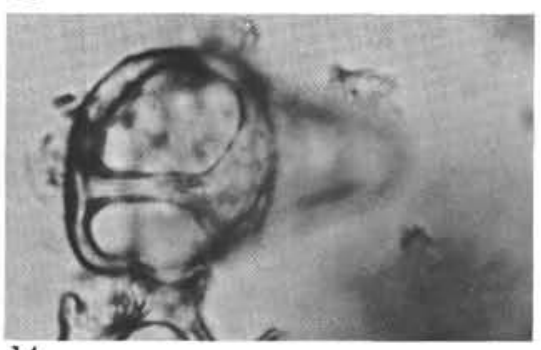

14

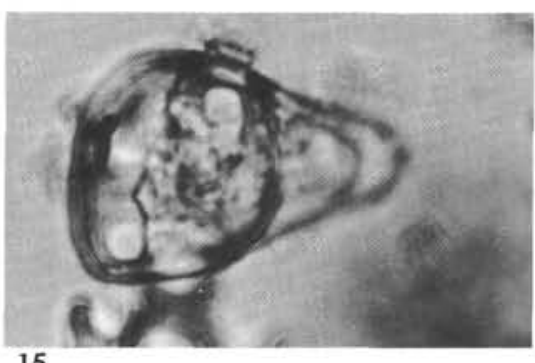

15 
PLATE 3

Silicoflagellates from DSDP Leg 36

Scale bar equals $10 \mu \mathrm{m}$ for all figures.

Figures 1-7 Corbisema glezerae n. sp.

1. USNM 221594, Sample 327A-8-1, 130-132 cm

(72 m).

2. USNM 221595, Sample 327A-8-1, 130-132 cm (72 m).

3. Holotype, USNM 221593, Sample 327A-6-3, $100-102 \mathrm{~cm}(56 \mathrm{~m})$.

4. USNM 221596. Sample 327A-5-5, 100-102 cm (49 m).

5. USNM 221597, Sample 327A-6-6, 130-132 cm (61 m).

6, 7. USNM 221598, Sample 327A-5-2, 100-102 $\mathrm{cm}(45 \mathrm{~m})$, side view, high and mid focuses.

Figures 8-15 Corbisema hastata cunicula n. subsp.

8. USNM 221600, Sample 327A-5-2, 100-102 cm (45 m).

9. USNM 221601, Sample 327A-6-1, 9-10 cm (52 $\mathrm{m})$.

10. USNM 221602, Sample 327A-6-6, 130-132 cm

$(61 \mathrm{~m})$.

11. USNM 221603. Sample 327A-5-2, 100-102 cm

(45 m).

12. USNM 221604, Sample 327A-5-2, 100-102 cm

(45 m).

13. USNM 221605, Sample 327A-5-2, 100-102 cm (45 m).

14. USNM 221606, Sample 327A-5-2, 100-102 cm $(45 \mathrm{~m})$.

15. Holotype, USNM 221599, Sample 327A-6-6, $130-132 \mathrm{~cm}(61 \mathrm{~m})$. 
PLATE 3
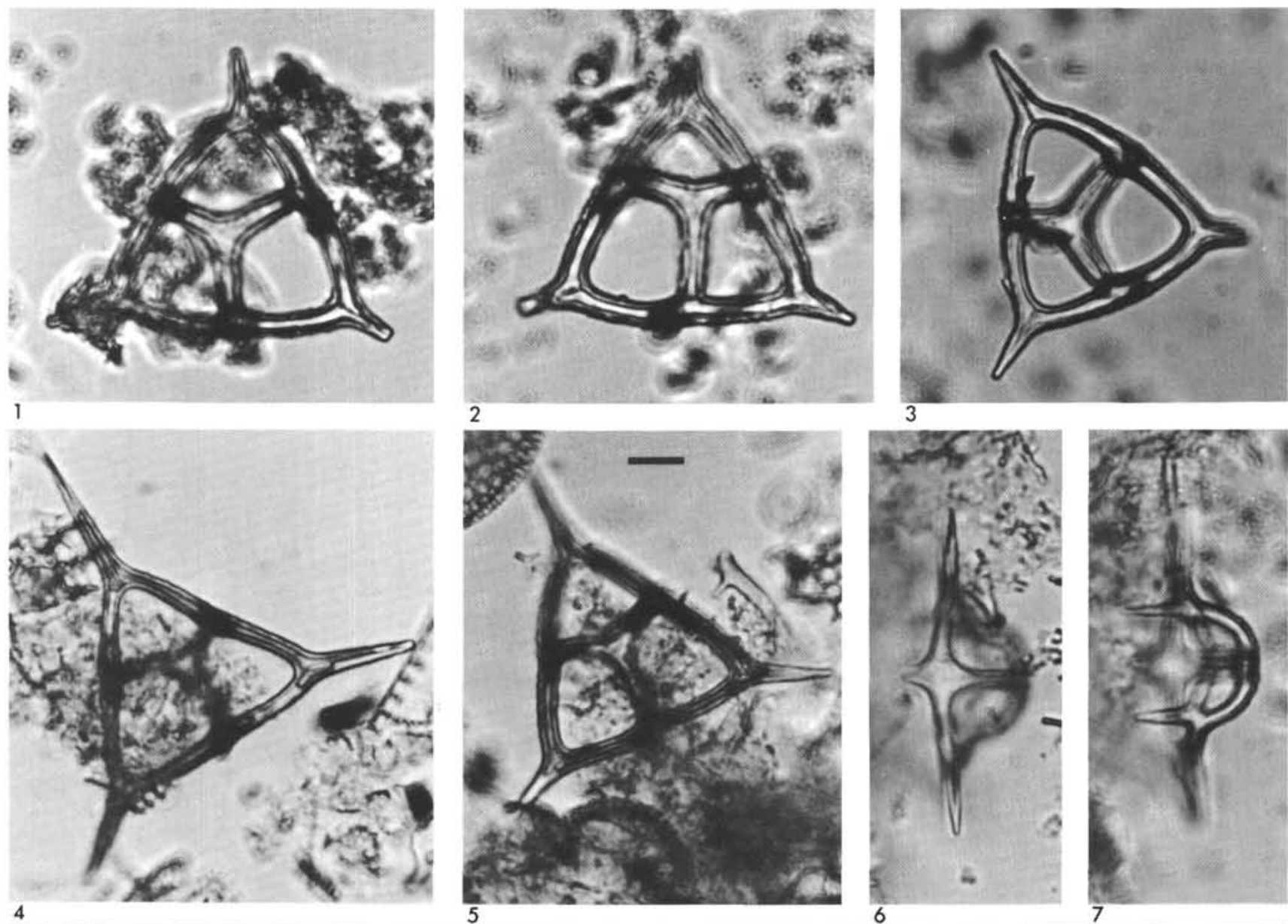

3
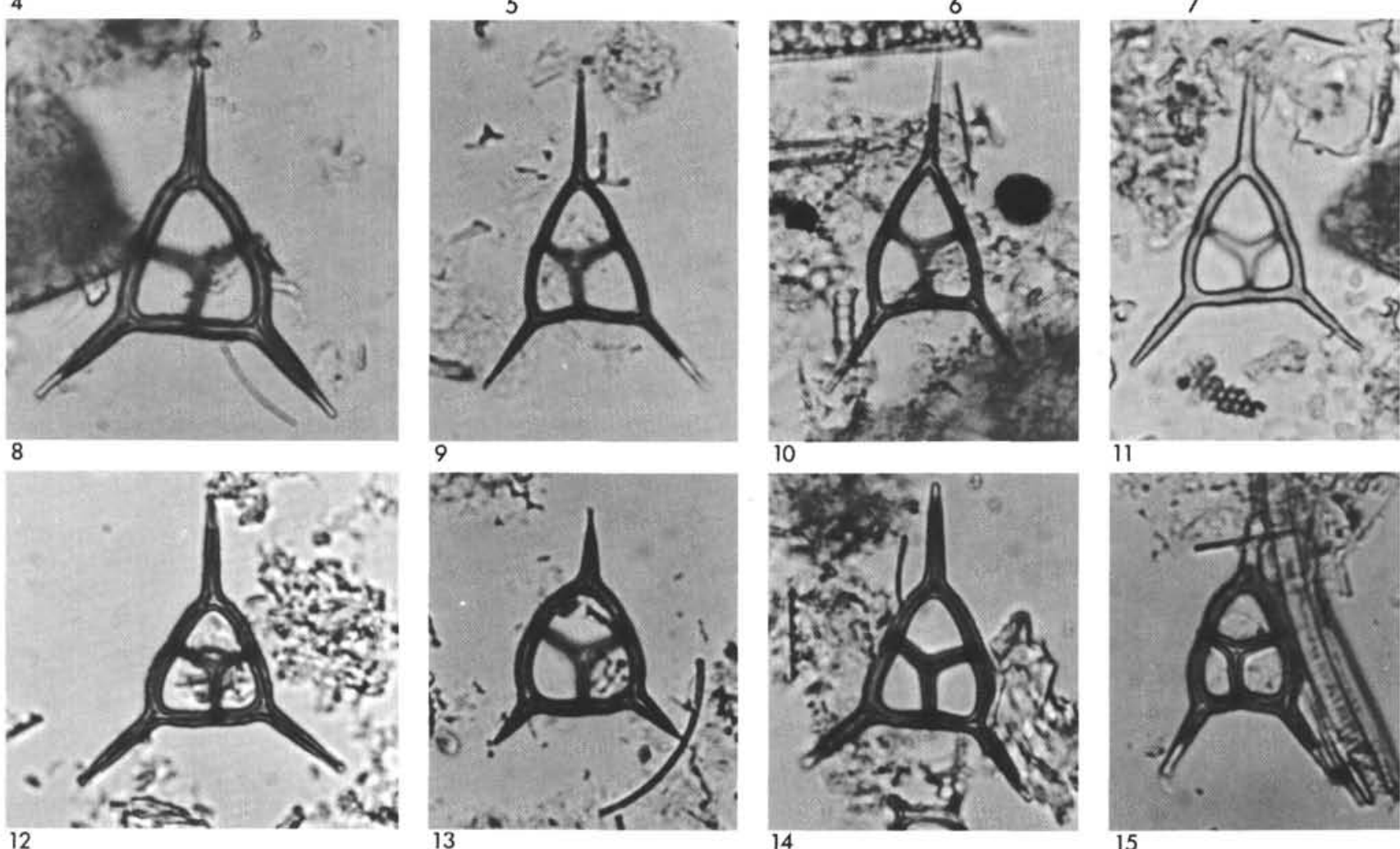


\section{PLATE 4}

Silicoflagellates from DSDP Leg 36

Scale bar equals $10 \mu \mathrm{m}$ for all figures.

Figures 1-8 Corbisema hastata globulata n. subsp.

1. USNM 221608, Sample 327A-5-4, 100-102 cm (48 m).

2. Holotype, USNM 221607, Sample 327A-5-4, $100-102 \mathrm{~cm}(48 \mathrm{~m})$.

3. USNM 221609, Sample 327A-5-2, 100-102 cm $(45 \mathrm{~m})$.

4. USNM 221610, Sample 327A-6-1, 9-10 cm (52 $\mathrm{m})$.

5. USNM 221611, Sample 327A-6-3, 100-102 cm (56 m).

6. USNM 221612, Sample 327A-7-2, 3-4 cm (62 $\mathrm{m})$.

7. USNM 221613, Sample 327 A-5-2, 100-102 cm (45 m).

8. USNM 221614, Sample 327A-5-2, 100-102 cm (45 m).

Figures 9-16 Corbisema hastata hastata (Lemmermann)

9. Sample 327A-6-1, 9-10 cm (52 m).

10. Sample 327A-5-6, $130-131 \mathrm{~cm}(51 \mathrm{~m})$.

11. Sample 327A-6-6, 130-132 cm (61 m).

12. Sample $327 \mathrm{~A}-6-1,9-10 \mathrm{~cm}(52 \mathrm{~m})$.

13. Sample $327 \mathrm{~A}-5-2,100-102 \mathrm{~cm}(45 \mathrm{~m})$.

14. Sample 327A-6-3, 100-102 cm (56 m).

15. Sample 327A-6-3, 100-102 cm (56 m).

16. Sample $327 \mathrm{~A}-5-5,100-102 \mathrm{~cm}(49 \mathrm{~m})$. 
PLATE 4
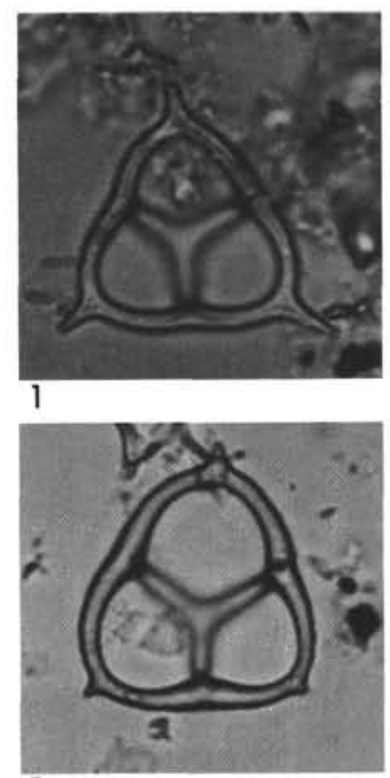

5
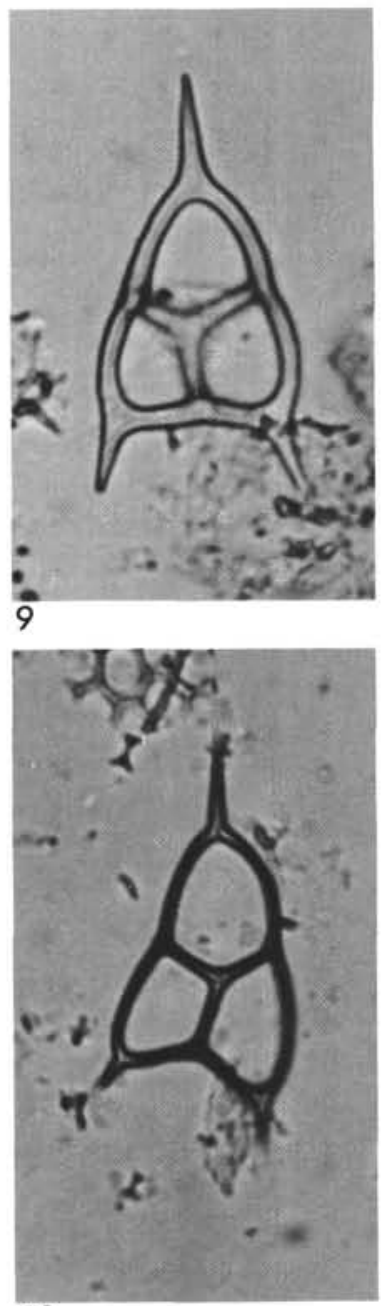

13
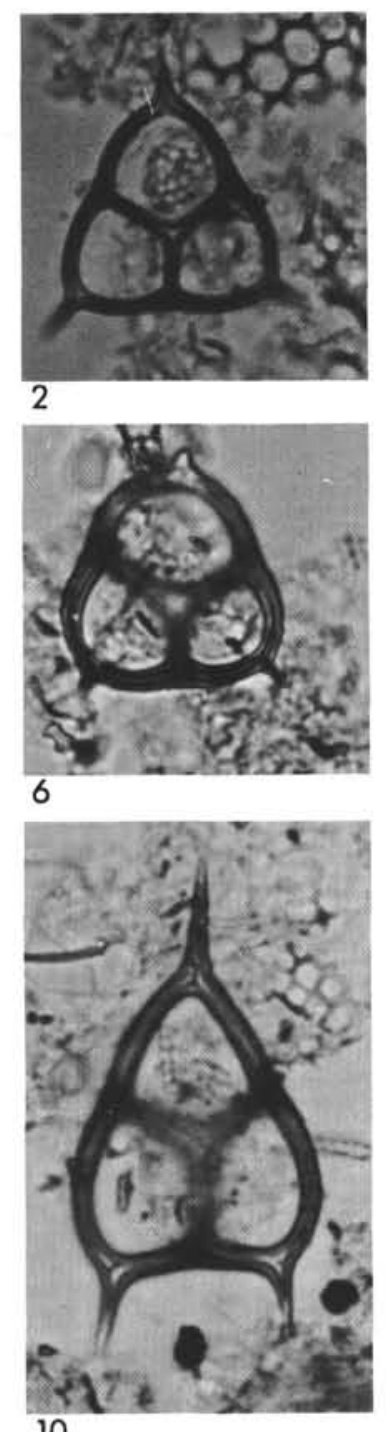

10

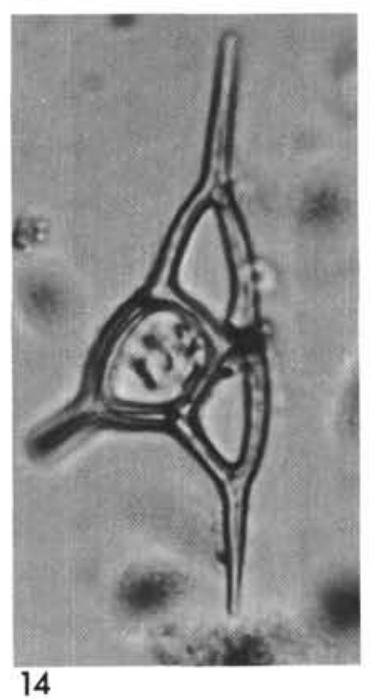

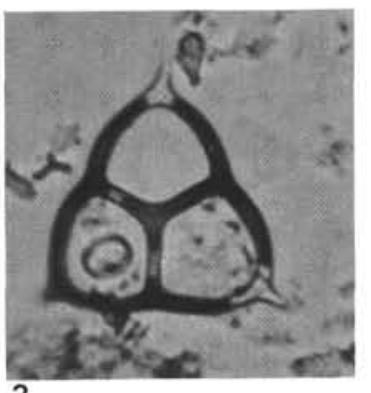

3
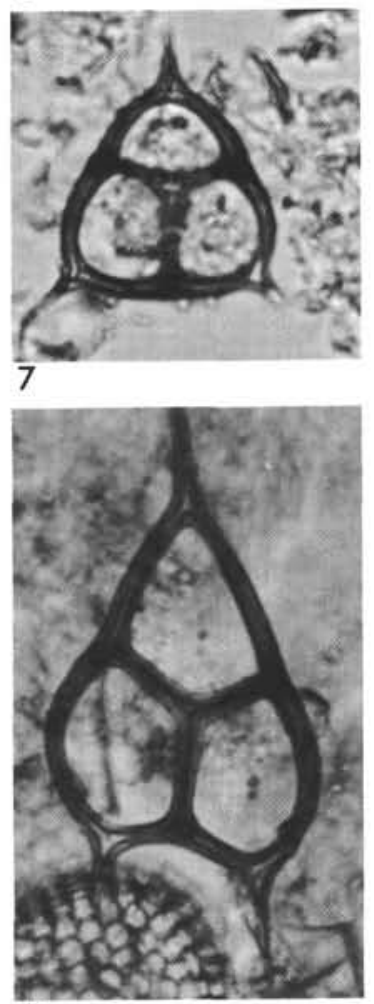

11

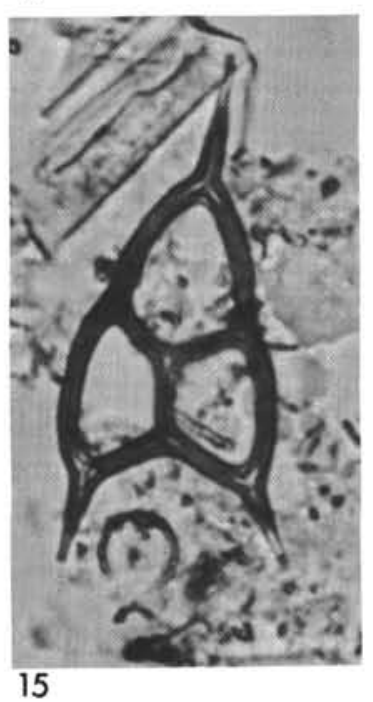

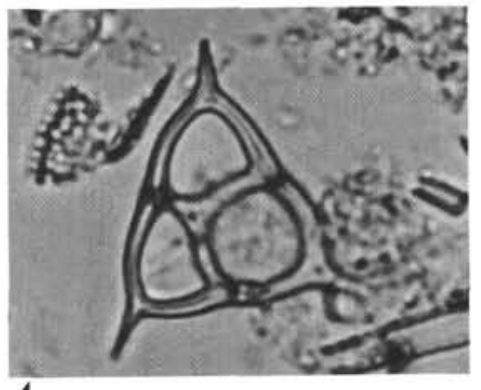

4
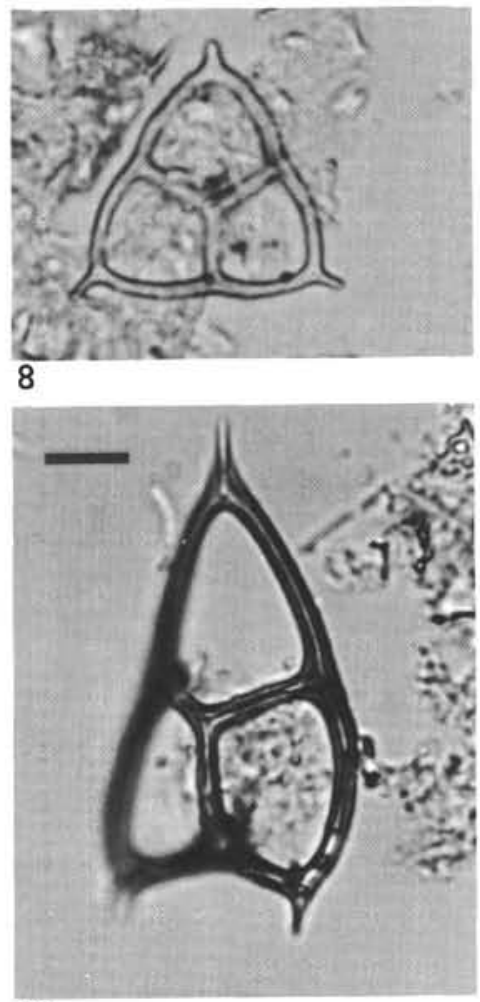

12

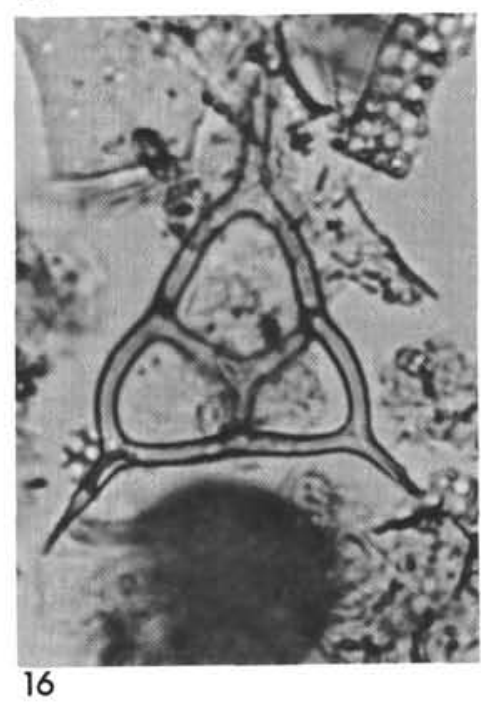




\section{PLATE 5}

Silicoflagellates from DSDP Leg 36

Scale bar equals $10 \mu \mathrm{m}$ for all figures.

Figures 1-3 Corbisema inermis inermis (Lemmermann)

1, 2. Sample 327A-5-1, 60-62 cm (43 m).

3. Sample $327 \mathrm{~A}-6-6,130-132 \mathrm{~cm}(61 \mathrm{~m})$, isosceles specimen.

Figures 4-7 Corbisema inermis minor (Glezer) n. comb. 4, 5. Sample 327A-5-4, 100-102 cm (48 m), basal and apical focuses.

6, 7. Sample $327 \mathrm{~A}-7-2,3-4 \mathrm{~cm}(62 \mathrm{~m})$, basal and apical focuses.

Figures 8-13 Corbisema neoparallela n. sp.

8. USNM 221616, Sample 327A-5-1, 60-62 cm (43 $\mathrm{m})$, fragment.

9. Holotype, USNM 221615, Sample 327A-5-2, $100-102 \mathrm{~cm}(45 \mathrm{~m})$.

10. USNM 221617, Sample 327A-5-1, 60-62 cm $(43 \mathrm{~m})$, tilted.

11. USNM 221618, Sample 327A-5-1, 60-62 cm (43 m).

12, 13. USNM 221619, Sample 327A-5-1, 60-62 $\mathrm{cm}(43 \mathrm{~m})$, tilted, two focus levels. 

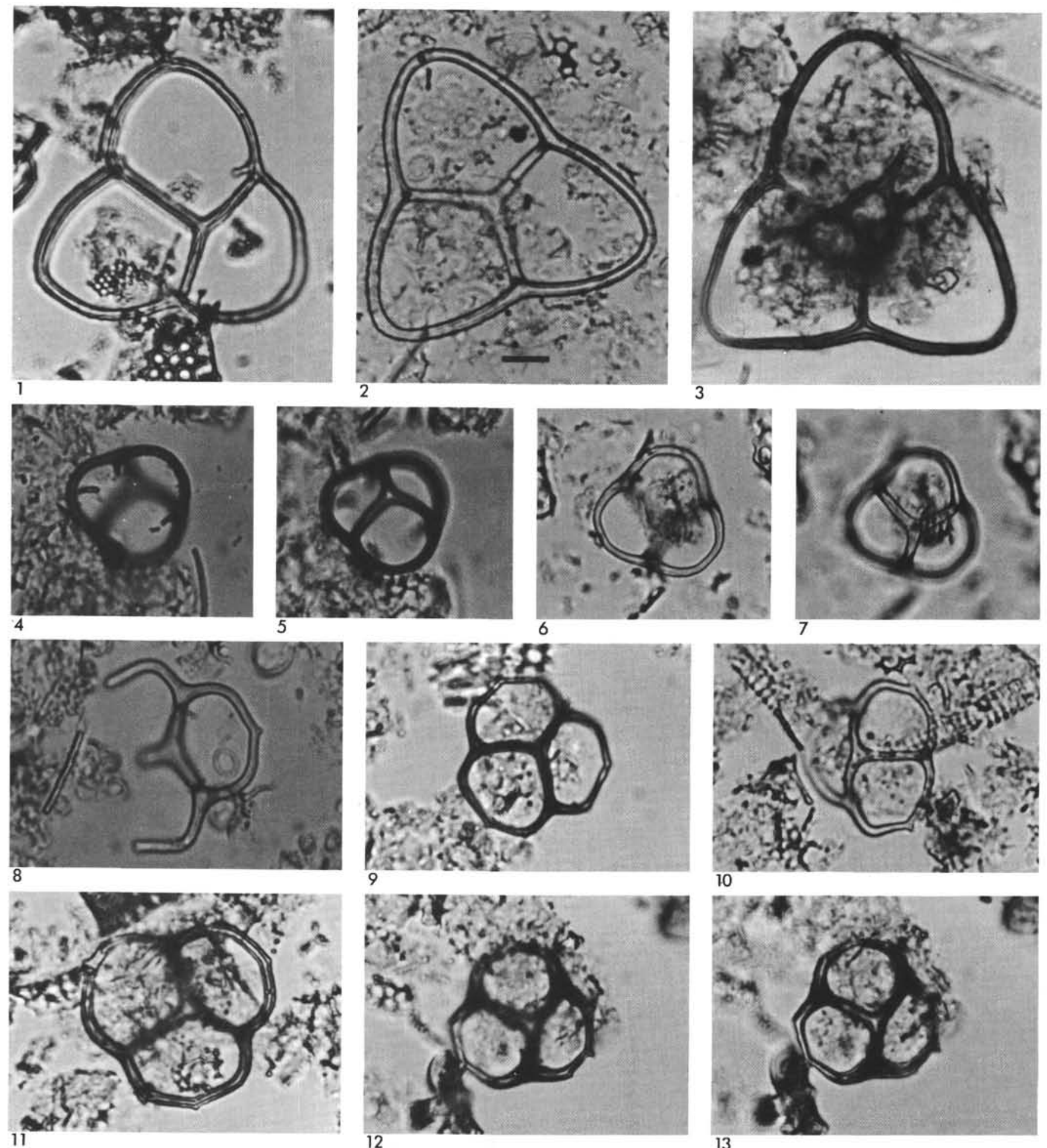


\section{PLATE 6}

Silicoflagellates from DSDP Leg 36

Scale bar equals $10 \mu \mathrm{m}$ for all figures.

Figures 1-5 Dictyocha fibula augusta n. subsp.

1-3. Holotype, USNM 221620, Sample 329-18-2, $50-51 \mathrm{~cm}(163 \mathrm{~m})$, basal, mid, and apical focuses. 4, 5. USNM 221621, Sample 329-18-2, 50-51 cm $(163 \mathrm{~m})$, basal and apical focuses.

Figures 6-13 Dictyocha precarentis n. sp.

6. USNM 221623, Sample 327A-8-1, 130-132 cm (72 m).

7. USNM 221624 , Sample 327 A-8-3, $43-44 \mathrm{~cm}$ (74 $\mathrm{m})$.

8. USNM 221625, Sample 327A-8-1, 130-132 cm (72 m).

9. USNM 221626, Sample 327-8-3, $43-44 \mathrm{~cm}$ (74 $\mathrm{m})$, abnormal specimen.

10, 11. Holotype, USNM 221622, Sample 327A$8-3,43-44 \mathrm{~cm}(74 \mathrm{~m})$, apical and basal focuses.

12. USNM 221627, Sample 327A-8-3, 43-44 cm (74 m).

13. USNM 221628, Sample 327A-5-6, 130-131 cm $(51 \mathrm{~m})$. 
PLATE 6
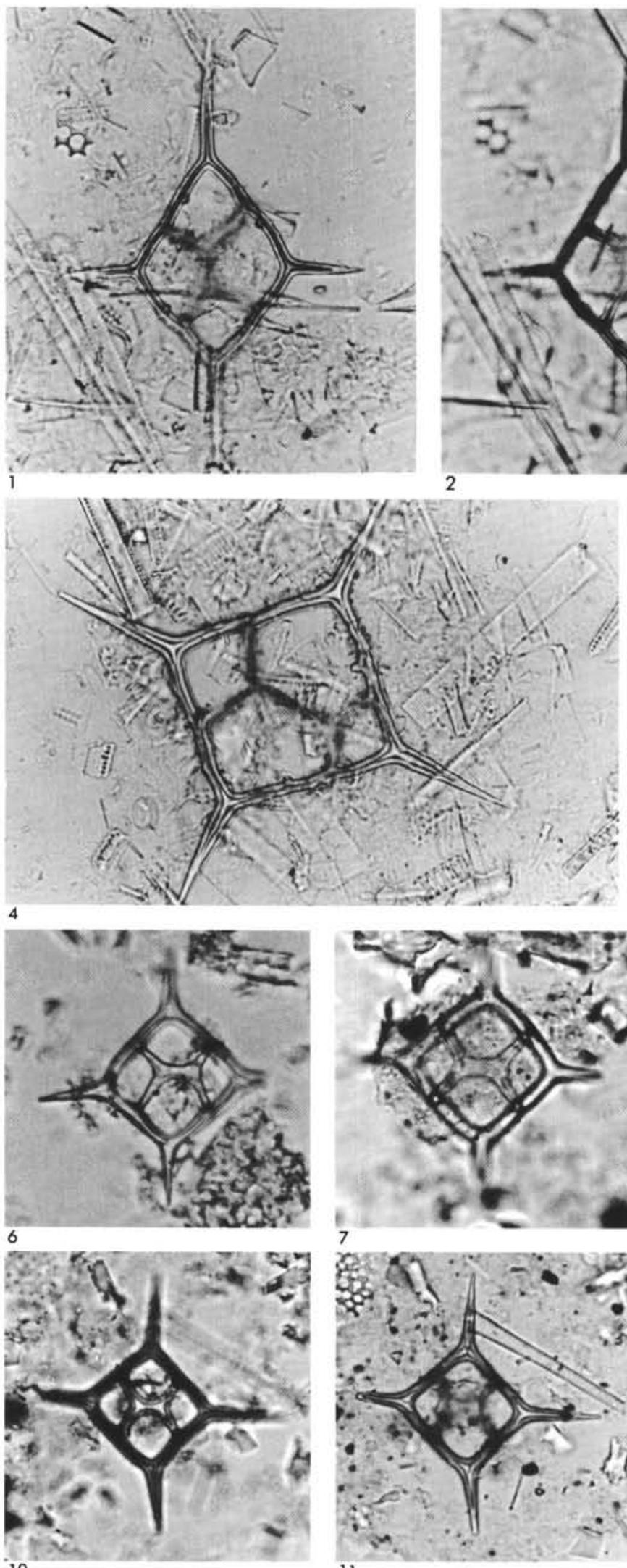
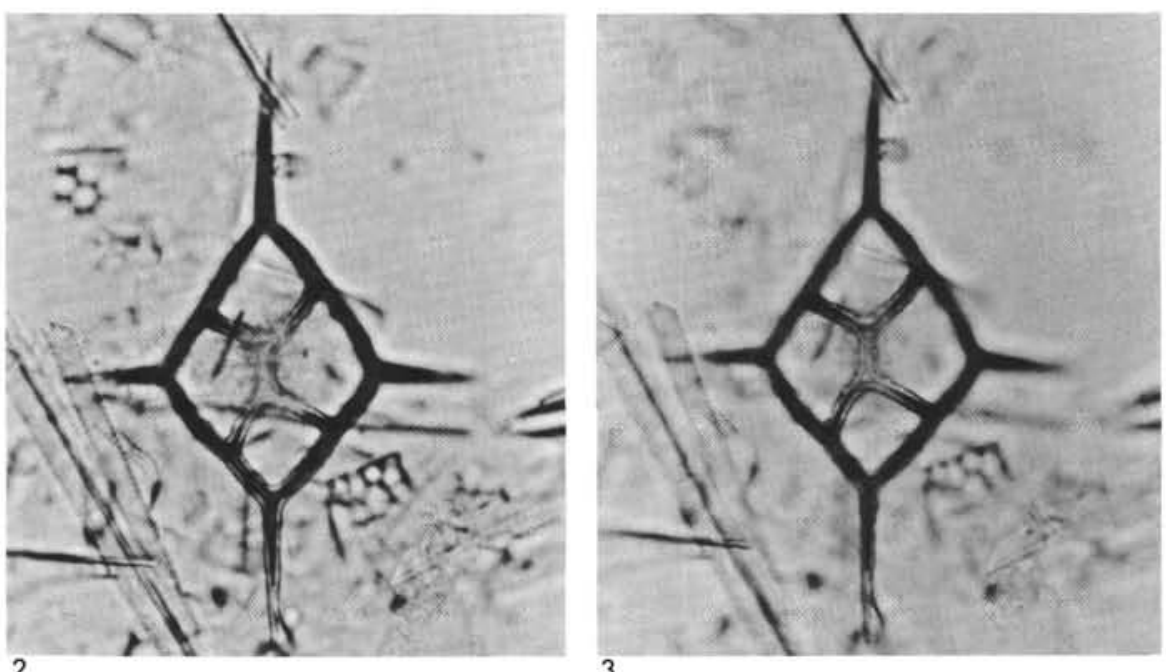

3
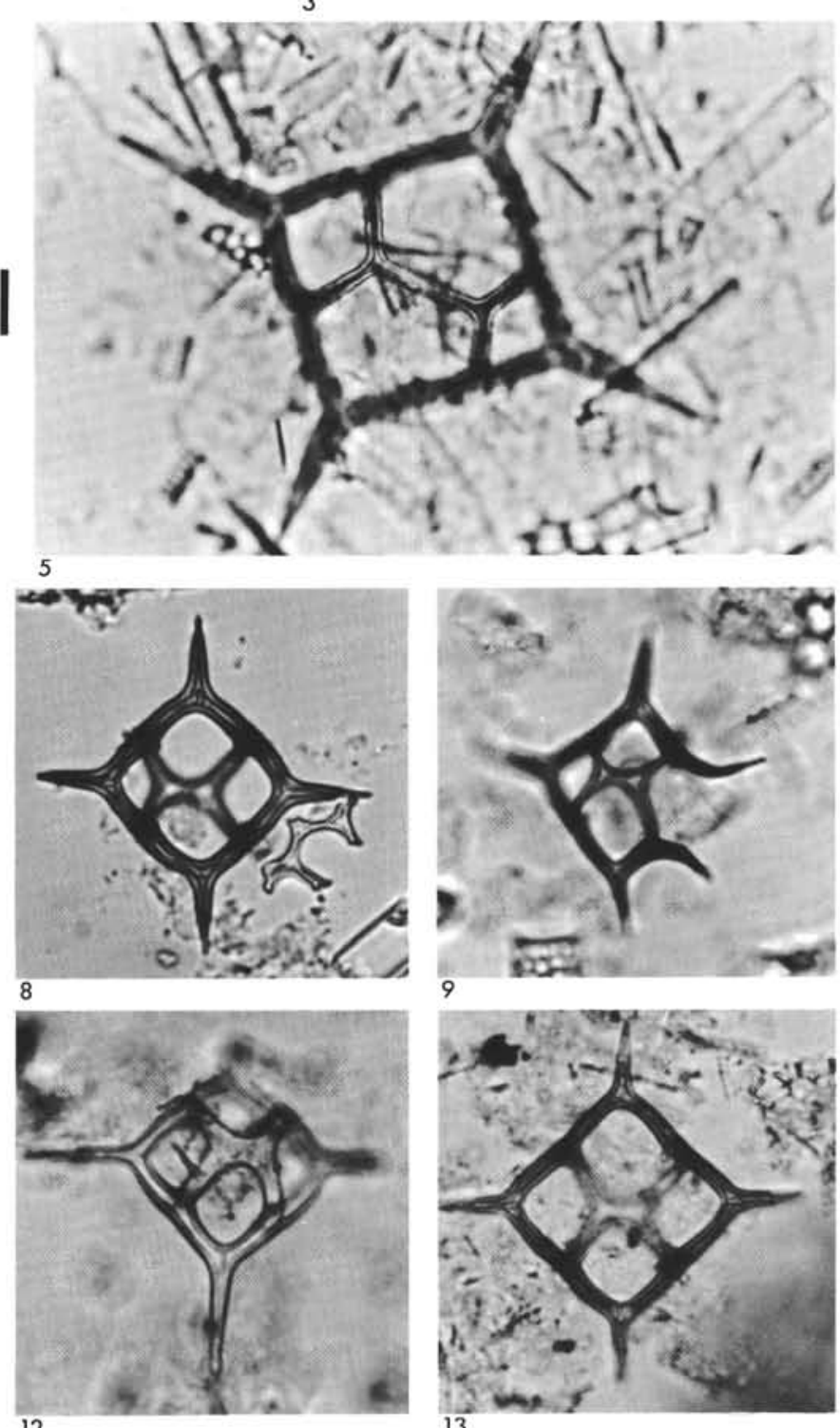


\section{PLATE 7}

Silicoflagellates from DSDP Leg 36.

Figures 1-11, 14, 15; scale bar equals $10 \mu \mathrm{m}$.

Figures 12, 13; scale bar equals $10 \mu \mathrm{m}$.

Figures 1-3 Dictyocha precarentis $\mathrm{n}$. sp.

1. USNM 221629 , Sample 327A-8-3, 43-44 cm (74

$\mathrm{m})$.

2, 3. USNM 221630, Sample $327 \mathrm{~A}-8-3,43-44 \mathrm{~cm}$ $(74 \mathrm{~m})$, basal and apical focuses.

Figures 4-13 Distephanus crux darwinii n. subsp.

4. USNM 221632. Sample 328B-3-3, 95-96 cm (31 $\mathrm{m})$.

5. USNM 221633. Sample 328B-3-1, 109-110 cm (28 m).

6, 7. Holotype, USNM 221631, Sample 328B-3-1, $109-110 \mathrm{~cm}(28 \mathrm{~m})$, basal and apical focuses.

8. USNM 221634, Sample 328B-3-3, $95-96 \mathrm{~cm}$ (31 $\mathrm{m})$.

9. USNM 221635. Sample 328B-3-1, 109-110 cm (28 m).

10,11. USNM 221636, Sample 328B-3-1, 109-110 $\mathrm{cm}(28 \mathrm{~m})$, basal and apical focuses.

12 , 13. USNM 221637, Sample 328B-3-1, 109-110 $\mathrm{cm}(28 \mathrm{~m})$, frenguelloid variant, basal and apical focuses.

Figures 14, 15 Distephanus raupii $\mathrm{n}$. sp.

14,15 . Holotype, USNM 221638, Sample 328B-3-

$5,100-102 \mathrm{~cm}(34 \mathrm{~m})$, basal and apical focuses. 
PLATE 7
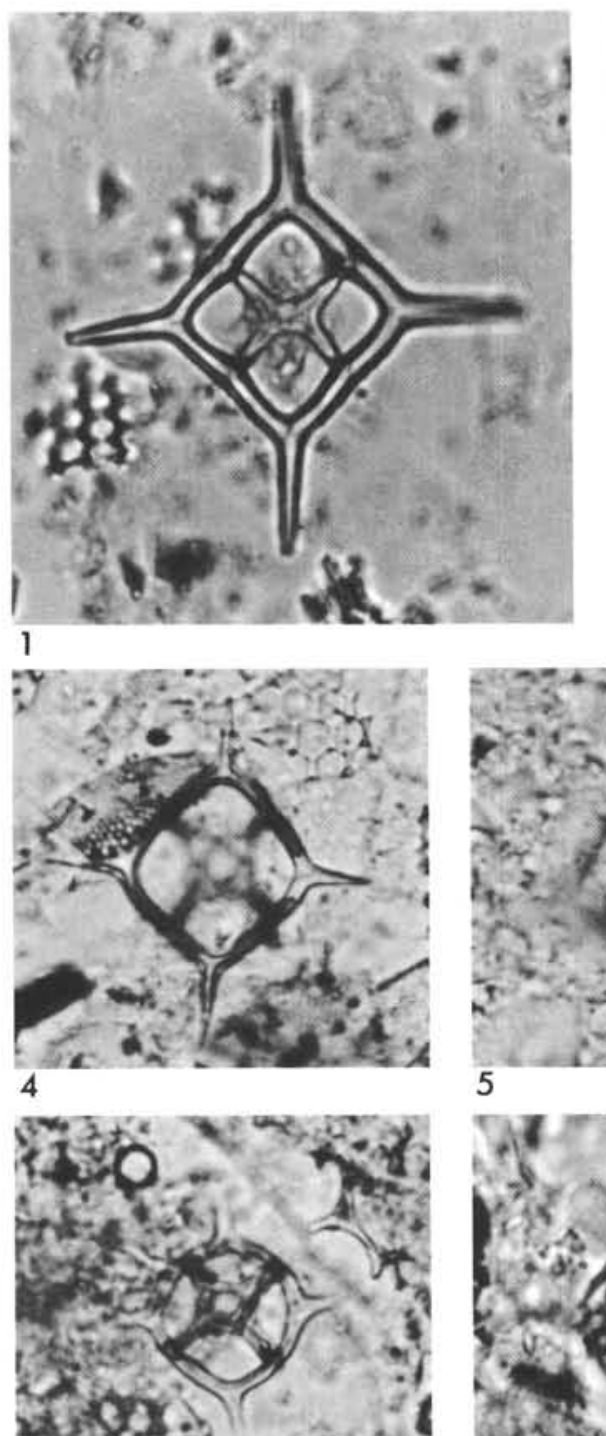

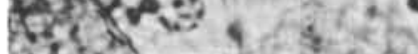
2.5. 8

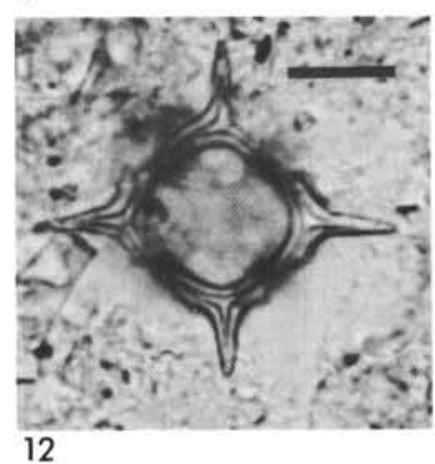

5

9
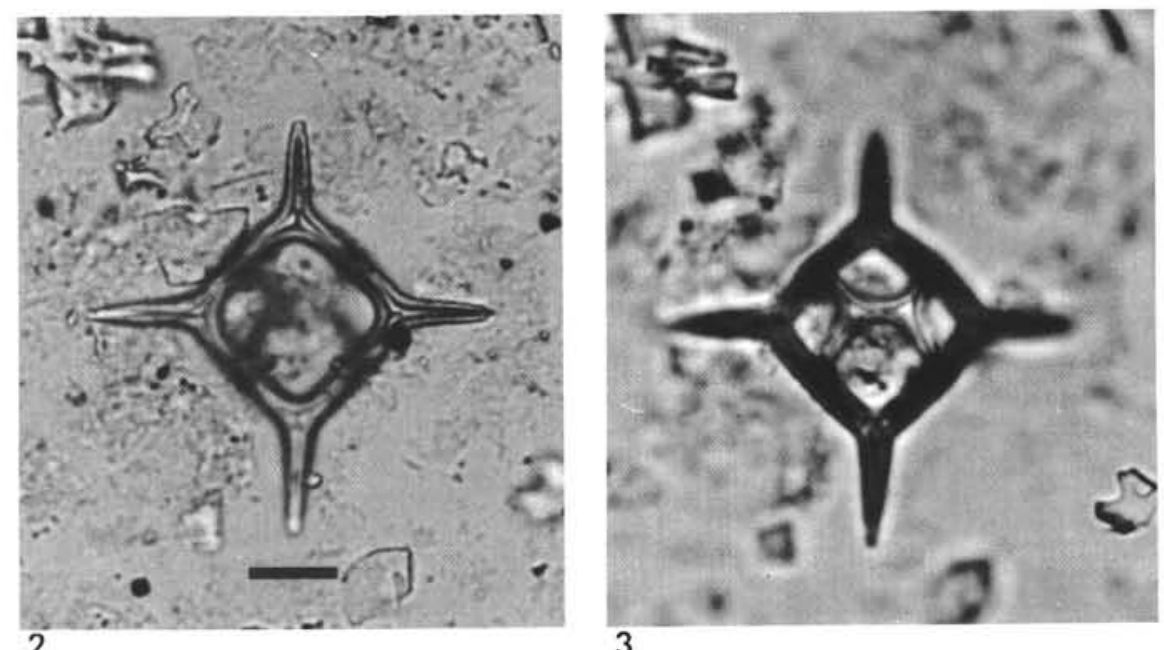

3
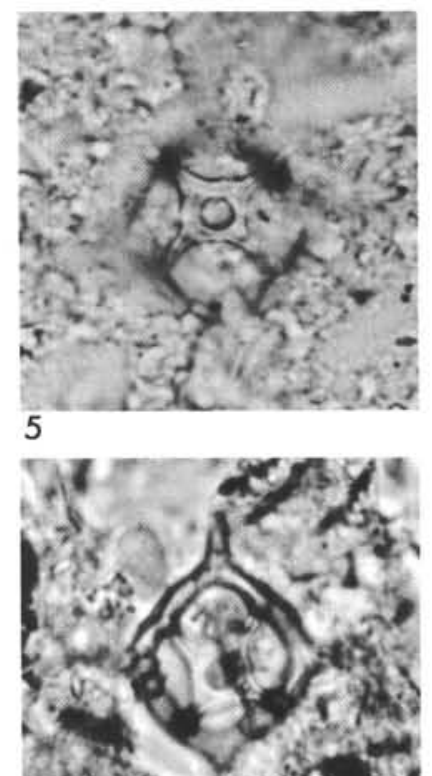

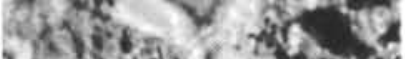

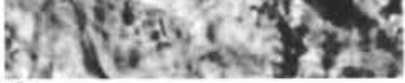

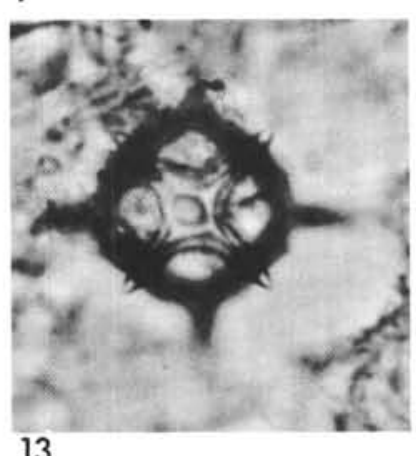

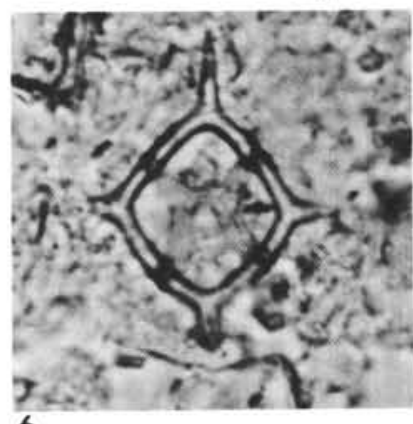

6

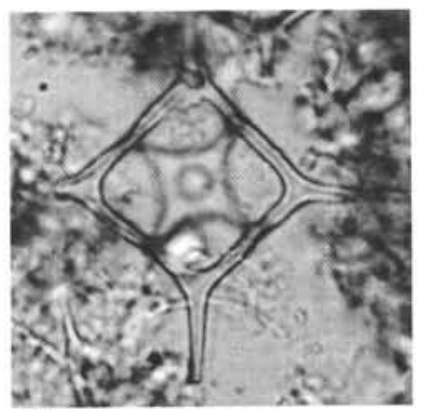

10

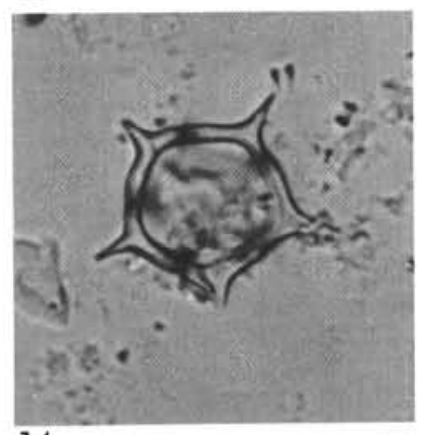

14

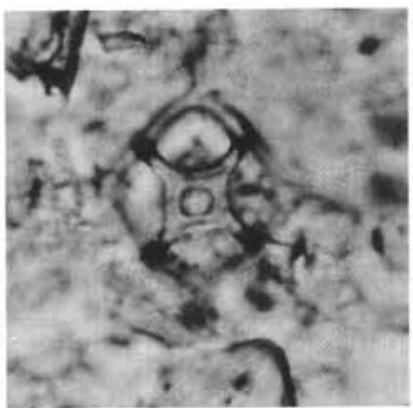

7

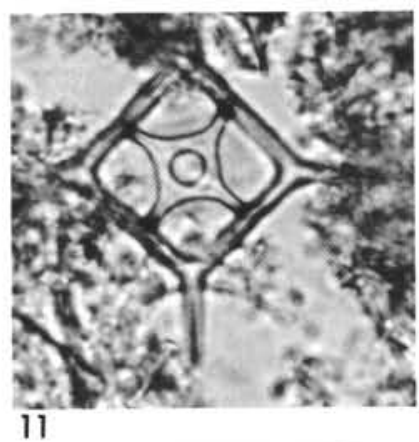

11

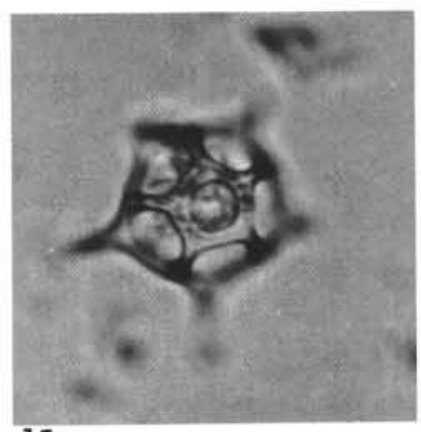




\section{PLATE 8}

Silicoflagellates from DSDP Leg 36

Figures 1-7, 10-12; scale bar equals $10 \mu \mathrm{m}$.

Figures 8, 9; scale bar equals $10 \mu \mathrm{m}$.

Figures 1-3 Distephanus speculum minutus (Bachmann)

1. Sample $329-12-2,50-51 \mathrm{~cm}(106 \mathrm{~m})$, pentagonal.

2. Sample $329-15-2,50-51 \mathrm{~cm}(134 \mathrm{~m})$.

3. Sample 329-4-3, 50-51 cm (31 m), octagonal.

Figures 4, 6 Distephanus speculum (Ehrenberg) s. ampl., abnormal

4. Sample 328-2-4, 2-3 cm (11 m), spineless.

6. Sample $328-2-4,2-3 \mathrm{~cm}(11 \mathrm{~m})$, swirled and binoculoid.

Figure 5 Distephanus sp. cf. D. boliviensis boliviensis (Frenguelli)

5. Sample $328-2-4,2-3 \mathrm{~cm}(11 \mathrm{~m})$, swirled.

Figures 7-10 Distephanus speculum varians Gran and Braarud 7. Sample 328-2-4, 2-3 cm (11 m), symmetric. 8, 9. Sample $329-1-3,50-51 \mathrm{~cm}(3 \mathrm{~m})$, double skeleton; 8 , high focus; 9 , low focus.

10. Sample $328-2-4,2-3 \mathrm{~cm}(11 \mathrm{~m})$, asymmetric.

Figures 11, 12 Naviculopsis sp. cf. N. aspera (Schulz)

11. Sample 327A-5-2, 100-102 cm (45 m).

12. Sample $327 \mathrm{~A}-5-1,60-62 \mathrm{~cm}(43 \mathrm{~m})$, abnormal specimen. 
PLATE 8
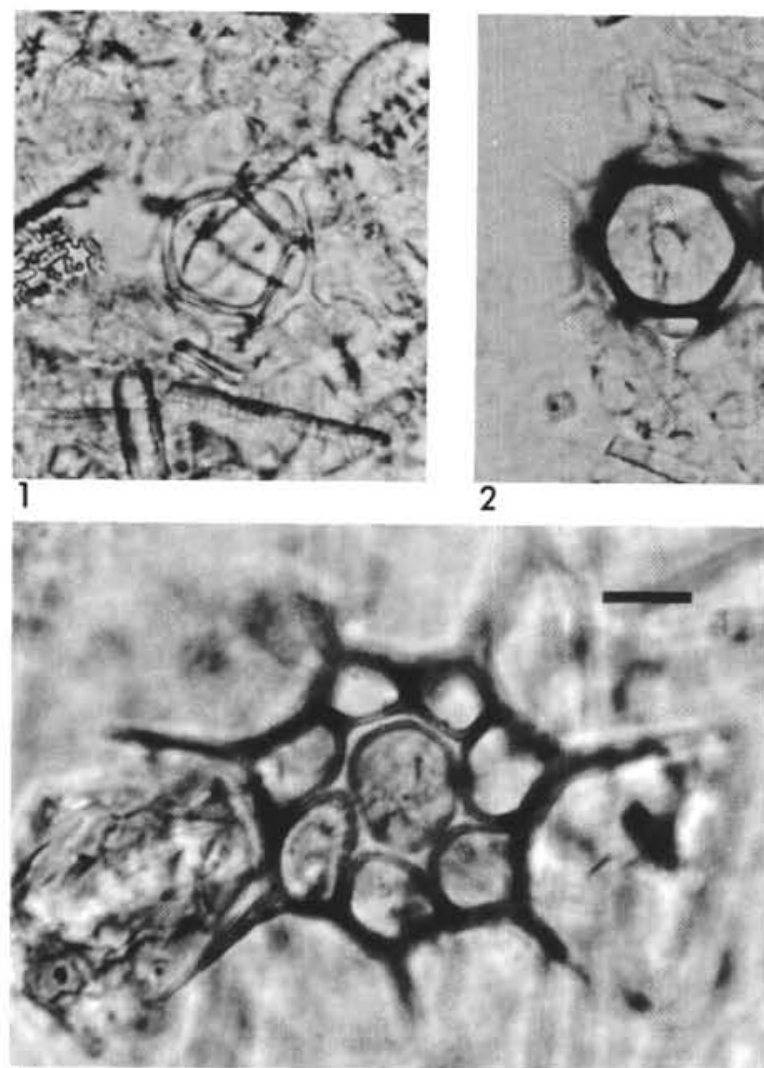

5

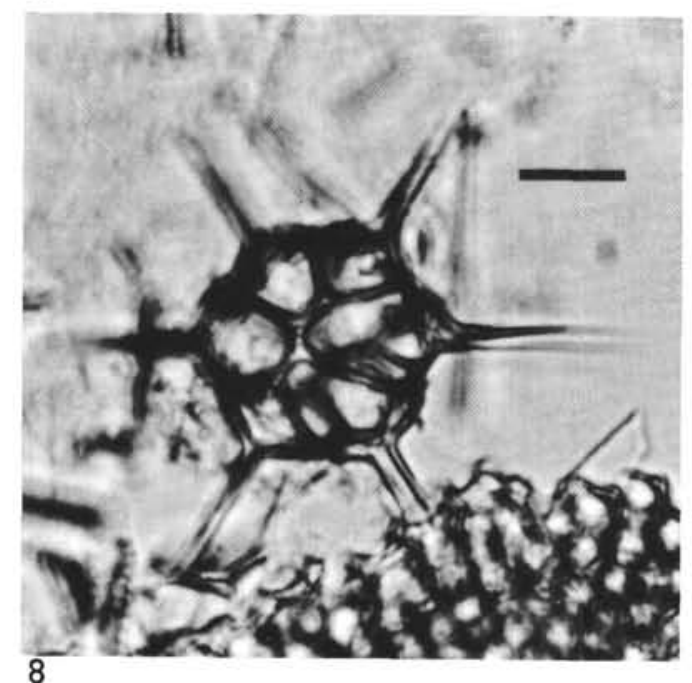

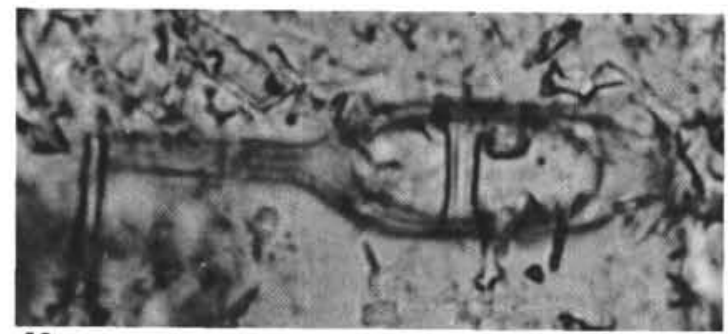

11
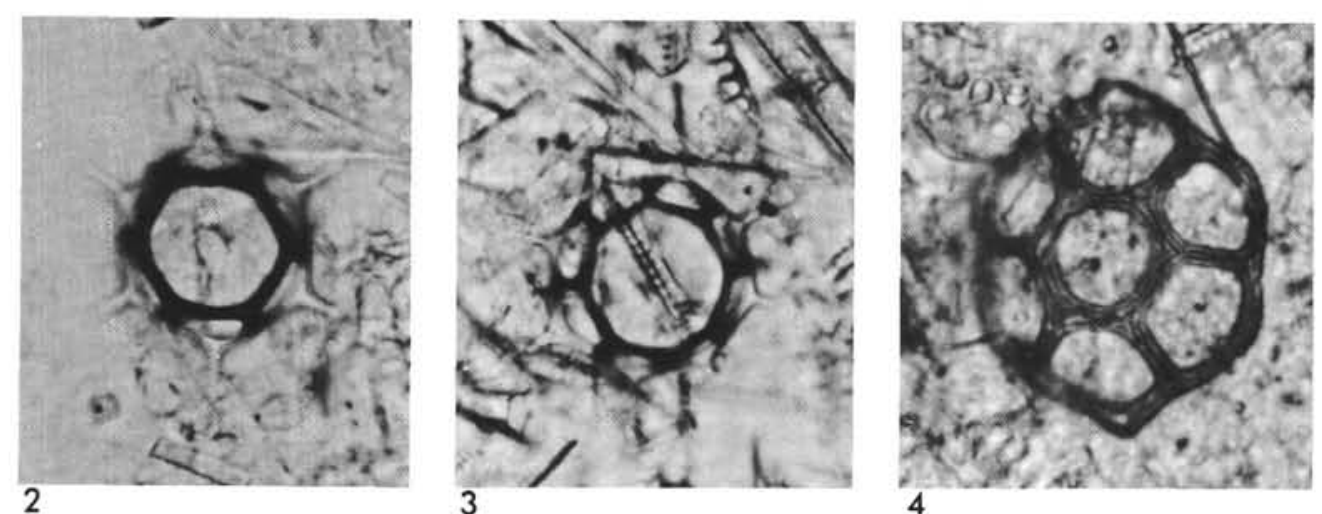

4

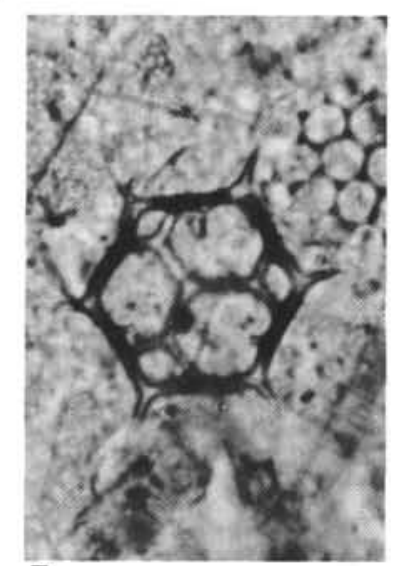

7
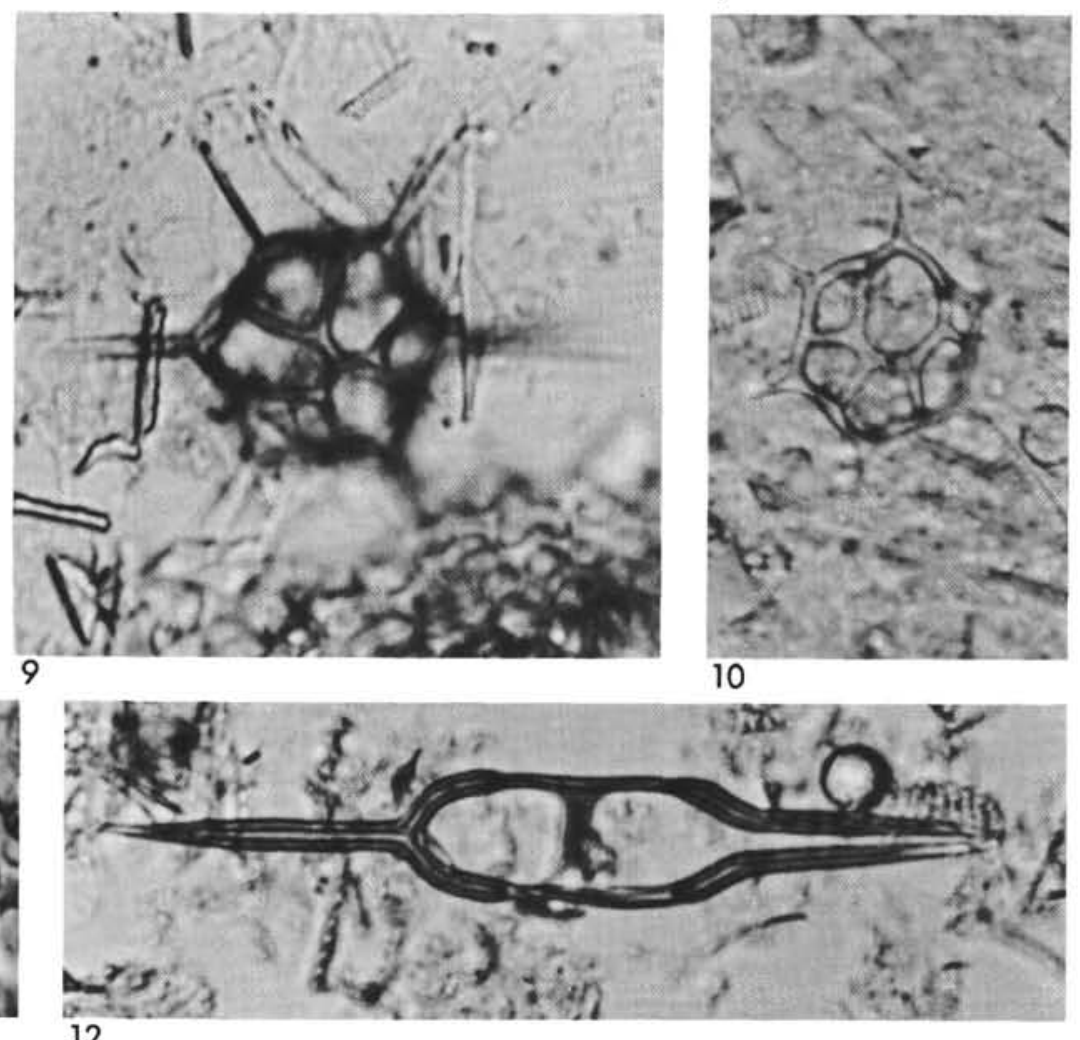


\section{PLATE 9}

Silicoflagellates and diatoms from DSDP Leg 36 and Baja California

Figures 1-5, 7-9; scale bar equals $10 \mu \mathrm{m}$.

Figure 6; scale bar equals $5 \mu \mathrm{m}$.

Figures 1, $2 \quad$ Naviculopsis constricta (Schulz)

1. Sample 327A-5-2, 100-102 cm (45 m).

2. Sample 327 A-5-4, 100-102 cm (48 m).

Figure 3 Naviculopsis danica Perch-Nielsen

3. Sample $327 \mathrm{~A}-8-1,130-132 \mathrm{~cm}(72 \mathrm{~m})$.

Figures 4-9 Stictodiscus gelidus Mann

4. Sample 328B-3-5, 100-102 cm (34 m).

5-9. Sample CAS54064, San Gregorio, Baja

California; 5-7, plan views; 8 and 9, side views. 
PLATE 9
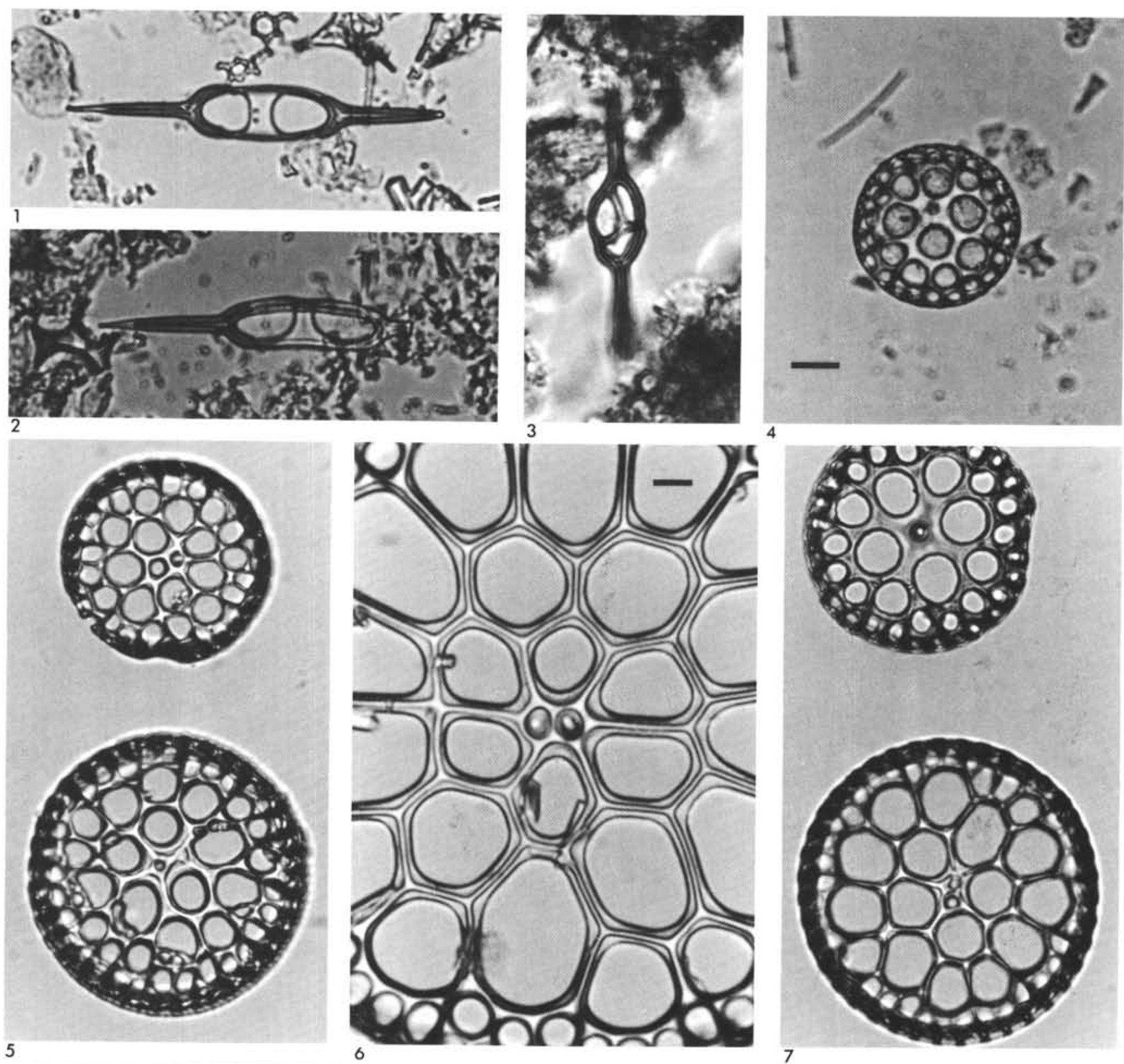

80.000 .0$.

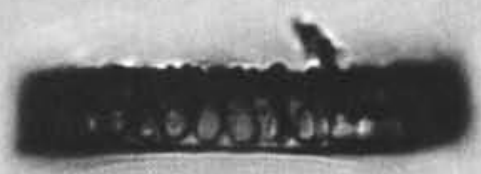

